\title{
Sustainable business model innovation: The role of boundary work for multi-stakeholder alignment
}

Citation for published version (APA):

Velter, M., Bitzer, V., Bocken, N., \& Kemp, R. (2020). Sustainable business model innovation: The role of boundary work for multi-stakeholder alignment. Journal of Cleaner Production, 247(119497), [119497]. https://doi.org/10.1016/j.jclepro.2019.119497

Document status and date:

Published: 20/02/2020

DOI:

10.1016/j.jclepro.2019.119497

Document Version:

Publisher's PDF, also known as Version of record

Document license:

Taverne

Please check the document version of this publication:

- A submitted manuscript is the version of the article upon submission and before peer-review. There can be important differences between the submitted version and the official published version of record.

People interested in the research are advised to contact the author for the final version of the publication, or visit the DOI to the publisher's website.

- The final author version and the galley proof are versions of the publication after peer review.

- The final published version features the final layout of the paper including the volume, issue and page numbers.

Link to publication

\footnotetext{
General rights rights.

- You may freely distribute the URL identifying the publication in the public portal. please follow below link for the End User Agreement:

www.umlib.nl/taverne-license

Take down policy

If you believe that this document breaches copyright please contact us at:

repository@maastrichtuniversity.nl

providing details and we will investigate your claim.
}

Copyright and moral rights for the publications made accessible in the public portal are retained by the authors and/or other copyright owners and it is a condition of accessing publications that users recognise and abide by the legal requirements associated with these

- Users may download and print one copy of any publication from the public portal for the purpose of private study or research.

- You may not further distribute the material or use it for any profit-making activity or commercial gain

If the publication is distributed under the terms of Article $25 \mathrm{fa}$ of the Dutch Copyright Act, indicated by the "Taverne" license above, 


\title{
Sustainable business model innovation: The role of boundary work for multi-stakeholder alignment
}

\author{
M.G.E. Velter ${ }^{\text {a, }{ }^{*}, \text { V. Bitzer }}{ }^{\text {a, b }}$, N.M.P. Bocken ${ }^{c, d}$, R. Kemp ${ }^{\text {a, e }}$ \\ ${ }^{a}$ Maastricht University, International Centre for Integrated Assessment and Sustainable Development, P.0. Box 616, 6200, MD, Maastricht, the Netherlands \\ ${ }^{\mathrm{b}}$ KIT Royal Tropical Institute, P.O. Box 95001, 1090 HA, Amsterdam, the Netherlands

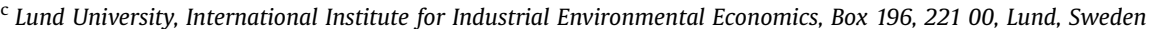 \\ ${ }^{\mathrm{d}}$ Delft University of Technology, Department of Industrial Design Engineering, Landbergstraat 15, 2628 CE, Delft, the Netherlands \\ e Maastricht Economic and Social Research Institute on Innovation and Technology (UNU-MERIT), United Nations University, 6211 AX Maastricht, The \\ Netherlands
}

\section{A R T I C L E I N F O}

\section{Article history:}

Received 31 December 2017

Received in revised form

22 October 2019

Accepted 28 November 2019

Available online 29 November 2019

Handling Editor: Yutao Wang

Keywords:

Sustainable value creation

Sustainable business model innovation

Boundary work

\begin{abstract}
A B S T R A C T
This study focuses on the boundary-spanning nature of sustainable business model innovation, studying multi-stakeholder engagement and alignment. Drawing on the concept of boundary work, we explore the different types of organizational boundary changes between focal companies and their external stakeholders, investigating specifically the process of exploring, negotiating, disrupting and realigning organizational boundaries. Based on an exploratory study of nine different sustainable business model initiatives from for-profit and non-profit organizations, our analysis shows how actors involved need to find alignment at normative, instrumental and strategic dimensions in order to achieve sustainable value creation. However, complexity for alignment emerges through different understandings of value, diverging interests, division of risks and responsibilities, and existing processes and activities that limits actors' openness to align. Mutual boundary changes are thus necessary in the process of multistakeholder engagement in order to enhance organizations' understanding of value and to capture the envisioned value. This paper functions as an agenda-setting paper, presenting first insights on how the boundary work lens can advance our understanding of alignment processes between focal organizations and their external stakeholders, required for sustainable business model innovation.
\end{abstract}

๑) 2019 Elsevier Ltd. All rights reserved.

\section{Introduction}

Companies are increasingly challenged to make the pursuit of social and environmental objectives part of their fundamental logic of 'doing business'. It seems undeniable that this would involve radical forms of reorganizing the business model on a firm and systems' level, questioning both what and how value is created and captured (Evans et al., 2017a; Stubbs and Cocklin, 2008). While conventional business models focus on "satisfying customer needs, economic return and compliance" (Bocken et al., 2015, p. 70), sustainable business models (SBMs) have a much broader scope in their ambition to generate positive or eliminate negative societal impacts. They integrate multiple dimensions of economic, social and environmental value, and they exceed the customer

\footnotetext{
* Corresponding author.

E-mail address: myrthe.velter@maastrichtuniversity.nl (M.G.E. Velter).
}

orientation of conventional business models by considering value creation to a broad scope of stakeholders, society and the natural environment (Bocken et al., 2015; Schaltegger et al., 2015). Studies have therefore argued that the required fundamental changes in the purpose of business and in many aspects of how it is conducted necessitate sustainable business model innovation (SBMI) (Bocken et al., 2014; Schaltegger et al., 2015; Stubbs and Cocklin, 2008). This innovation process concerns, among others, the development of new value propositions, value creation and delivery networks, and value capture mechanisms (Teece, 2010).

Such an encompassing process of SBMI calls for a broader network perspective and entails that companies engage with a wider set of actors, including customers, suppliers and partners, NGOs and the government (Bocken et al., 2014; Boons and LüdekeFreund, 2013). Thus, what was already pronounced in 'conventional' business model innovation, becomes even more apparent in sustainable business model innovation: it exceeds the organizational boundaries of the focal firm. The call for engaging with 
stakeholders is grounded in the expectation that not only are they potentially affected by SBMI, they also have something to contribute. Bocken et al. (2016) discuss stakeholders' roles in supporting "extending resource value" and "extending product value". Other studies emphasize the processes of experimentation and learning between firms and stakeholders, required to combine sustainability solutions at the level of firms' business models with system-wide change (Quist and Tukker, 2013; Rohrbeck et al., 2013; Stubbs and Cocklin, 2008). Similarly, studies on circular business models echo the need for multi-stakeholder engagement to find innovative solutions for closed loop supply chains (Leising et al., 2018).

At the same time, engaging in extensive interaction with external stakeholders requires extra efforts and is recognized as one of the key challenges in SBMI (Evans et al., 2017b; Geissdoerfer et al., 2018). Most importantly, stakeholders may possess different perceptions of value, they may have different and conflicting objectives and material interests, and they may be characterized by fundamental power imbalances (Bolton and Landells, 2015; Di Domenico et al., 2009; Powell et al., 2018). SBMI thus requires alignment of stakeholders' interests and demands (Bocken et al., 2013). Yet, while the literature has highlighted the need to further explore companies' relations with external stakeholders in SBMI (Boons and Lüdeke-Freund, 2013; Stubbs and Cocklin, 2008), how this happens in practice is still relatively underexplored (Pieroni et al., 2019).

To contribute to this discussion on how focal organizations engage with external stakeholders for SBMI, we draw on the concept of boundary work, which is about finding ways to accommodate such differences between stakeholders (Bocken et al., 2019). Boundary work can be broadly understood as actors' efforts to explore, create, maintain and challenge existing organizational boundaries through concrete efforts, including the use of boundary spanners (e.g. organizations, people, objects) and boundary management (e.g. communication practices) (Zietsma \& Lawrence, 2010). Specifically, we frame boundary work in SBMI as a process of exploring, negotiating, disrupting and realigning organizational boundaries. This will be further explained in the following section.

This paper functions as an agenda-setting paper, presenting first insights on the ways in which boundary work advances our understanding of the processes of alignment between focal organizations and external stakeholders in SBMI. This serves to contribute to the pending question of how organizations can innovate their business models towards greater levels of sustainability (Foss and Saebi, 2017). Specifically, the paper responds to recent calls for further research on the processes by which organizations innovate SBMs in a multi-stakeholder setting (Bocken et al., 2019; Dentchev et al., 2018; Roome and Louche, 2016). Focusing on the multi-stakeholder aspect of SBMI, where actors' visions and interests for sustainability meet and potentially conflict, may also provide a way forward to promote stronger forms of SBMs (Upward and Jones, 2016). By approaching multistakeholder alignment as boundary work, we aim to add a practice-based perspective that helps organizations to address the challenges of stakeholder relations during the process of SBMI (Geissdoerfer et al., 2018). The outline of this paper is as follows: section 2 describes the literature on sustainable business models, multi-stakeholder alignment and its complexities, resulting in the relevance of a boundary work lens for SBMI. The methods are described in section 3. Section 4 presents the results of the exploratory and validating interviews, which are being discussed and concluded in section 5 .

\section{Literature review}

\subsection{From business models to sustainable business models}

All organizations are incomplete and depend on exchanges with other systems to survive (Scott, 1998). The interactions of companies and their external environment, including stakeholders, are key to the discussion on business models and sustainable business models. Zott and Amit (2010, p. 216) have conceptualized a firm's business model as a "system of interdependent activities that transcends the focal firm and spans its boundaries". This indicates that business models go beyond organizational boundaries as the socially constructed "demarcation between the organization and its environment" (Santos and Eisenhardt, 2005, p. 491). While organizational boundaries are rarely explicit, they can be conceptualized as boundaries of 'efficiency' (denoting which transactions an organization conducts internally and which ones are conducted externally), boundaries of 'power' (focusing on how organizations can control their exchange relations), boundaries of 'competence' (delineating an organisation's resources, capabilities and knowledge), and boundaries of 'identity' (pertaining to understandings of 'who we are' as an organization) (Santos and Eisenhardt, 2005). Such boundaries are not static, but emerge and change through interactions with other actors (Abbott, 1995; Schreyögg and Sydow, 2010).

Business models extend organizational boundaries in that they link the focal firms' resources, capabilities and activities through value creation outside the firm, in particular with partners, suppliers, shareholders and customers (Barney et al., 2001; Eisenhardt \& Martin, 2000; Teece, 2010). Thus, while often not explicitly defined, firms' activities to relate to third parties to organise transactions and minimise costs or to harness their knowledge, ideas and technologies (Berglund and Sandström, 2013), touch upon different organizational boundaries, such as efficiency and competence (Santos and Eisenhardt, 2005).

The boundary-spanning nature of business models is even more pronounced in sustainable business models, which can be defined as "business models that incorporate pro-active multi-stakeholder management, the creation of monetary and non-monetary value for a broad range of stakeholders, and hold a long-term perspective" (Geissdoerfer et al., 2018). At the centerpiece of this definition lies the notion of a sustainable value proposition - economic, social and environmental value, consisting of value captured, missed, destroyed, wasted and new value opportunities on both short- and long term for a broad range of stakeholders, including society and environment (Bocken et al., 2013). Sustainable business models therefore comprise a value proposition to customers, delivered by a wide value creation and delivery network, and a value capture mechanism that captures economic value for the business while simultaneously regenerating natural, social and economic value beyond organizational boundaries (Schaltegger et al., 2016) (see also Table 1). In addition to considerations of efficiency and competence boundaries, sustainable business models implicitly relate to identity boundaries, drawing on organizations' shared values and norms in a particular social context (Santos and Eisenhardt, 2005).

\subsection{Different dimensions of stakeholder alignment in sustainable business model innovation}

Transforming the logic by which business generate and distribute value requires a process of innovation, either to develop entirely new business models, diversify into additional business 
Table 1

Value as a as a multi-dimensional, multi-relational and multi-level concept.

\begin{tabular}{|c|c|c|c|}
\hline & Business Model & Sustainable Business Model & Key sources \\
\hline Value form & Value created and captured & $\begin{array}{l}\text { Value created and captured plus value absence, destroyed, missed } \\
\text { or surplus, new value opportunities }\end{array}$ & Bocken et al., 2013; Evans et al., 2017 \\
\hline Value priority & Economic first & Societal \& environmental value first or equal to economic value & $\begin{array}{l}\text { Schaltegger et al., 2016; Stubbs and Cocklin, } \\
2008\end{array}$ \\
\hline Value horizon & Direct, short- or medium- term & Direct, short- or medium- term plus indirect, long-term & Madden, 2017; Stubbs and Cocklin, 2008 \\
\hline Value proposition & Customer value & $\begin{array}{l}\text { Sustainable customer value and co-benefits through value for } \\
\text { society \& environment }\end{array}$ & $\begin{array}{l}\text { Bocken and Allwood, 2012; Boons and Lüdeke- } \\
\text { Freund, 2013; Patala et al., } 2016\end{array}$ \\
\hline $\begin{array}{l}\text { Value creation \& } \\
\text { delivery network }\end{array}$ & $\begin{array}{l}\text { Business, value chain, relevant } \\
\text { network partners }\end{array}$ & $\begin{array}{l}\text { Business and interlinked value chains plus value network } \\
\text { including new and possibly non-traditional partners }\end{array}$ & $\begin{array}{l}\text { Chesbrough and Schwartz, 2007; Evans et al., } \\
2017\end{array}$ \\
\hline Value capture & $\begin{array}{l}\text { Economic business value } \\
\text { (monetary \& non-monetary) }\end{array}$ & Societal, environmental and economic value & $\begin{array}{l}\text { Boons and Lüdeke-Freund, 2013; Madden, } \\
\text { 2017; Schaltegger et al., } 2012\end{array}$ \\
\hline
\end{tabular}

*Full development of Table 1 can be found in Appendix A.

models, or transform from one business model to another (Geissdoerfer et al., 2018). In such a process of sustainable business model innovation (SMBI), firms need to not only conduct changes in their own organization, but depend on (re-)alignment with stakeholders. Firstly, any changes to the business model of a firm require changes in the business model of other actors - otherwise it will not work (Hellström et al., 2015). Secondly, sustainable business models extend the emphasis on stakeholder relationships, moving from value creation for customers, suppliers or other business partners, to value creation with and for stakeholders (Freudenreich et al., 2019), including customers, suppliers, business partners, NGOs, government actors and local communities (Boons and Lüdeke-Freund, 2013; Joyce and Paquin, 2016). As noted by Bocken et al. (2019), this engagement takes place in a 'value network' to denote the possibility of mutual value exchanges, where focal organizations explore and assess together with stakeholders issues such as value created, fairness, efficiency and effectiveness.

Focal organizations and stakeholders in their value network need to align on three distinct dimensions: normative, strategic and instrumental (Breuer and Lüdeke-Freund, 2017). At the normative dimension, sustainable business model innovation requires a redefinition of the purpose of the firm based on sustainable value (Stubbs and Cocklin, 2008). This involves a discussion between focal organizations and stakeholders on value propositions and how value is understood. Organizational boundaries are challenged, as value can only be created and captured across organizational boundaries (Brehmer et al., 2018). Alignment at normative dimension forms a foundation for decision-making and alignment at the strategic dimension (Bleicher, 1994; Breuer and LüdekeFreund, 2017).

At the strategic dimension, SBMI affects organizational boundaries as externalities formerly outside the business model, such as emissions or waste, are to be internalized (Bocken et al., 2015; Brehmer et al., 2018; Breuer and Lüdeke-Freund, 2017). This involves a discussion about which externalities can and should be internalized and how stakeholders can help in this; for instance, by adjusting their own activities. These shifting transactions need to be embedded in novel value propositions to create and capture mutual value. Decisions made at the strategic dimension direct implementation and execution at the instrumental dimension (AlDebei and Avison, 2010; Breuer and Lüdeke-Freund, 2017; Solaimani and Bouwman, 2012).

At the instrumental dimension, sustainable business model innovation necessitates a change of organizational activities and processes, such as novel product and service designs, distribution channels, and pricing schemes (Boons et al., 2016; Breuer and Lüdeke-Freund, 2017). Although innovation always entails a change in activities, the magnitude of novelty and change is both larger and more long-term in SBMI compared to conventional business model innovation. This is, for example, because activities involve longer returns on investments and higher uncertainty.

All three dimensions where stakeholder alignment is required thus affect organizational boundaries, both of the focal organization and its stakeholders. This includes changes in efficiency boundaries (e.g. new organisational activities), competence boundaries (e.g. new knowledge and skills) and identity boundaries (e.g. new purpose of an organisation).

\subsection{The challenges of stakeholder alignment}

While alignment between focal companies and stakeholders is deemed critical (Bocken et al., 2019; Freudenreich et al., 2019), its importance also explains why sustainable business model innovation is so tremendously difficult (Evans et al., 2017b).

Stakeholder engagement in itself requires extra efforts in sustainable business model innovation compared to conventional business model innovation (Geissdoerfer et al., 2018), much less to speak about successful alignment on normative, strategic and instrumental dimensions (Breuer and Lüdeke-Freund, 2017). As the business model innovation literature has long recognized, there is no executive control by the focal organization as to how stakeholders should behave to make business models successful (Berglund and Sandström, 2013). "A main source of complexity in business model innovation is given by the uncertainty of impacts and behaviors of network members regarding the three sustainability dimensions" (Evans et al., 2017b, p. 605). However, beyond acknowledging the challenges of stakeholder relations during the business model innovation process (Geissdoerfer et al., 2018), this component seems to be under-researched in the literature on SBMI (Pieroni et al., 2019).

The literature on cross-sector innovation helps to shed light on the inherent complexities of bringing together organizations with potentially dissimilar organizational interests and practices. Here scholars have pointed out that multi-stakeholder engagement often struggles with seemingly irreconcilable differences in the goals of partner organizations (Huxham and Vangen, 2000), dissimilar institutional logics (Vurro et al., 2010), differing value frames, norms and expectations (Dyer and Sing, 1998; Stark, 2009; Le Ber and Branzei, 2010a,b), unfamiliarity and mutual suspicion (Rondinelli and London, 2003) or cultural differences and misunderstandings (Berger et al., 2004). Organizations may possess competing material interests that influence their willingness and capability to align (Powell et al., 2018). Boundary dissonance, implying a lack of alignment of organizational boundaries between stakeholders for sustainable business model innovation - for instance, with regard to definitions of value or configuration of activities - is therefore likely to emerge (Stubbs and Cocklin, 2008). 
This is where tensions can arise between normative aspirations and capturing (at least some) financial value to secure economic sustainability and create opportunities for scaling-up (Bitzer and Hamann, 2015).

Where the multi-stakeholder context creates boundary dissonance, SBMI can be impeded. This makes the question of how to deal with boundary dissonance increasingly relevant. One assumption in the cross-sector innovation literature seems to be that conflict and tensions should be reduced or avoided to lessen their destructive forces (e.g. Googins and Rochlin, 2002; Crosby and Bryson, 2010). Others consider competing forces and value frames as vital ingredients for successful multi-stakeholder collaboration and innovation (Le Ber and Branzei, 2010a). Koschmann et al. (2012, p. 340) argue for the need for "surfacing and reclaiming - rather than ignoring and suppressing - relevant conflicts as a route to legitimate consent generation and ultimately, to broader support for collective decisions". Similarly, the business model literature mentions the traditional focus on control and gatekeeping, although this seems to be shifting towards a more dynamic approach. "It is precisely the alignment of control and value parameters that is of most relevance to business modelling" (Ballon, 2007, p. 7).

\subsection{Research gap: a boundary work perspective on SBMI}

Interactions across organizational boundaries and alignment of stakeholders are thus recognized as important for SBMI (Boons et al., 2016; Brehmer et al., 2018; Heracleous, 2004). However, there is still little knowledge on how focal organizations engage in processes of aligning with multiple stakeholders, specifically at normative, strategic and instrumental dimensions - all of which have implications for organizational boundaries. We approach such a process of exploring, establishing, reinforcing, disrupting and redesigning organizational boundaries between organizations and their stakeholders for SBMI from the perspective of 'boundary work' (Gieryn, 1983). We argue that framing SBMI as a boundary work process helps understanding these processes of alignment in multi-stakeholder engagement.

Originating from the science literature, the boundary work perspective aims to make sense of complex interactions between scientists and non-scientists in which roles of understanding and decision-making get blurred and re-asserted (Gieryn, 1983; Hoppe, 2010; Halffman, 2003). Strategic management literature mentions boundary spanning and brokerage to overcome differences and a lack of trust within an innovation community (Fleming and Waguespack, 2007). The concepts of boundary work, spanning and brokerage offer an interesting theoretical lens for understanding the interactions between prospective collaborators in a value network, i.e. between a focal organization and its external stakeholders, over relevant values, strategies and concrete actions for a new, sustainable business model. These interactions must suit the needs and interests of interdependent parties through multiple value creation, delivery and capture. Boundary work theory therefore investigates the concrete practices that enable conversation, interaction and coordinated action between the focal organziation and other actors, while accommodating actors to have their specific own value perspective, consideration and interests (Carlile, 2002; Halffman, 2003; Hoppe, 2010). Strategies to negotiate boundaries involve the use of boundary objects, such as texts, concepts and tools, and boundary spanners that help actors to have a shared reference. Such a shared reference, in turn, can serve to bridge differences discursively and materially through mutually aligned activities (Halffman, 2003; Hoppe, 2010). Boundary work for SBMI is about the coordination of mutually dependent activities without the use of external control.

Boundary work has also been applied in organizational theory (O’Mahony and Bechky, 2008; Smink et al., 2015; Zietsma \& Lawrence, 2010), focusing not only on boundary bridging but also on boundary manipulation. Challenging the state of boundaries is particularly apparent in SBMI, e.g. by different NGOs or consumer groups, legislation, public opinion or competitor strategies (Boons et al., 2016; Haaker et al., 2017; Smink et al., 2015). As boundaries have material consequences closely related to processes of status and monopolization, they are object of strategic consideration in which actors "struggle over and come to agree upon definitions of reality" and "maintain or disrupt systems of privilege" (Lamont and Molnar, 2002, p. 168). Zietsma and Lawrence (2010) therefore understand boundary work as "the attempts of actors to create, shape, and disrupt boundaries" (p. 190). Different practices of boundary work have been highlighted in the literature, including creating, redefining, disrupting or breaching, and bridging or crossing organizational boundaries (Carlile, 2002; O'Mahony and Bechky, 2008; Santos and Eisenhardt, 2005).

Our expectation is that the ways in which boundary work takes place, for example, the extent to which multilevel value creation is considered, influence the alignment of stakeholders' organizational boundaries important for SBMI. This makes boundary work relevant as a practitioner activity and as a theoretical lens to explore how organizations deal with boundaries.

\section{Methods}

\subsection{Case studies and case selection}

To analyse the role of boundary work in SBMI, we used an exploratory comparative case study approach whereby the unit of analysis is the company (Eisenhardt, 1989; Yin, 1994). This paper presents and compares nine cases of Dutch companies engaged in SBMI (Table 2). The chosen companies do not constitute a representative sample. Instead, given the emerging knowledge on SBMI (Lüdeke-Freund and Dembek, 2017), purposive sampling took place to identify information rich cases that can contribute to theory building (Eisenhardt, 1989; Patton, 1990). Both for-profit and nonprofit companies were selected as they represent different purposes and are expected to take different approaches to SBMI (Table 2).

\subsection{Data collection}

Empirical data was primarily collected through semi-structured interviews with key informants involved in the innovation process (Table 3). Data collection was divided into two rounds of empirical inquiry: firstly, exploratory interviews on the role of boundary work in SBMI from which the framework emerged, and secondly, validating interviews on the tentative boundary work framework. During the first round of interviews, topics of discussion included the envisioned value creation, the innovated business model and its novelty, role of collaboration and non-business stakeholders, challenges and tensions in the innovation process, critical turning points, conducted boundary work activities, and obstacles for enhancing value creation. Interviews were triangulated with a review of published documents such as annual reports, presentations, websites and brochures.

The second round of data collection aimed to get a clearer understanding of how individual firms conduct boundary work in SBMI and to validate insights gained through the initial interviews. 
Table 2

Case description, as emerged from empirical enquiry.

\begin{tabular}{|c|c|c|c|c|c|}
\hline Case & Organization & $\begin{array}{l}\text { Organization } \\
\text { type }\end{array}$ & $\begin{array}{l}\text { Innovation } \\
\text { phase }\end{array}$ & Sustainability aim ${ }^{\mathrm{a}}$ & Sustainable business models pursued \\
\hline 1 One & Heijmans & For-profit SME & Market & $\begin{array}{l}\text { To fill empty urban spaces and provide affordable housing for } \\
\text { young professionals through a modular, mobile home }\end{array}$ & $\begin{array}{l}\text { Sell to intermediaries, move to renewable } \\
\text { resources }\end{array}$ \\
\hline 2 Niaga & DSM-Niaga & $\begin{array}{l}\text { Joint venture } \\
\text { for-profit, MNE } \\
\text { and Start-up }\end{array}$ & Market & $\begin{array}{l}\text { To develop a mono-material carpet technology enabling } \\
\text { circular carpet flows }\end{array}$ & $\begin{array}{l}\text { CE closed loop manufacturing, low carbon } \\
\text { manufacturing, licensing, green chemistry }\end{array}$ \\
\hline 3 Futureproof & Kingspan & $\begin{array}{l}\text { For-profit, } \\
\text { MNE }\end{array}$ & Market & $\begin{array}{l}\text { To eliminate asbestos by replacing asbestos roofs of Dutch } \\
\text { farmers with Kingspan roofs, insulation and solar panels in a } \\
\text { cost-neutral way, using solar as financer }\end{array}$ & $\begin{array}{l}\text { Product as a service, move to renewable } \\
\text { resources }\end{array}$ \\
\hline $\begin{array}{l}4 \text { Ecor } \\
\text { Circular } \\
\text { Friesland }\end{array}$ & $\begin{array}{l}\text { Noble } \\
\text { Environmental }\end{array}$ & $\begin{array}{l}\text { For-profit, } \\
\text { MNE }\end{array}$ & Discovery & $\begin{array}{l}\text { To apply Ecor non-toxic mono-material cellulose fiber } \\
\text { production using (local) waste streams and applications in } \\
\text { Friesland Provence }\end{array}$ & $\begin{array}{l}\text { CE Industrial symbiosis, licensing, green } \\
\text { chemistry }\end{array}$ \\
\hline $\begin{array}{l}5 \text { Food-for- } \\
\text { Feed-for- } \\
\text { Food }\end{array}$ & $\begin{array}{l}\text { Nijsen- } \\
\text { Granico }\end{array}$ & For-profit SME & Discovery & $\begin{array}{l}\text { To create a circular and more sustainable food concept by } \\
\text { collecting retailers' food waste and turn it into pig feed }\end{array}$ & $\begin{array}{l}\text { CE closed loop manufacturing, industrial } \\
\text { symbiosis, choice editing by retailers, } \\
\text { responsible product promotion }\end{array}$ \\
\hline 6 Kipster & Kipster & $\begin{array}{l}\text { For-profit, } \\
\text { start-up }\end{array}$ & Market & $\begin{array}{l}\text { To produce world's most environmental, social, and animal- } \\
\text { friendly 'sustainable' egg }\end{array}$ & $\begin{array}{l}\text { Sell to retailer, low-carbon manufacturing, } \\
\text { move to renewable resources, choice editing by } \\
\text { retailers, responsible product promotion }\end{array}$ \\
\hline $\begin{array}{l}7 \text { Philips New } \\
\text { Karolinska }\end{array}$ & Royal Philips & $\begin{array}{l}\text { For-profit, } \\
\text { MNE }\end{array}$ & Market & $\begin{array}{l}\text { To increase access to healthcare in partnership with New } \\
\text { Karolinska Hospital, Sweden }\end{array}$ & $\begin{array}{l}\text { Performance-based PSS, extended producer } \\
\text { responsibility }\end{array}$ \\
\hline 8 BeeBanking & $\begin{array}{l}\text { Stroom The } \\
\text { Hague }\end{array}$ & $\begin{array}{l}\text { Non-profit, } \\
\text { SME }\end{array}$ & Market & $\begin{array}{l}\text { To increase citizen awareness of the importance of securing } \\
\text { biodiversity, specifically the role of bees in natural cycles, } \\
\text { placing urban bee-banks and using bee-banking }\end{array}$ & $\begin{array}{l}\text { Collaborative approaches, crowd sourcing, } \\
\text { biodiversity protection and regeneration } \\
\text { initiative ('net positive'), consumer education } \\
\text { and awareness, alternative banking }\end{array}$ \\
\hline 9 Thuisbaas & Urgenda & $\begin{array}{l}\text { Urgenda: Non- } \\
\text { profit, SME } \\
\text { Thuisbaas: For- } \\
\text { profit, SME }\end{array}$ & Market & $\begin{array}{l}\text { To accelerate residential retrofitting towards energy-neutral } \\
\text { houses in a cost-neutral way (solar as financer) }\end{array}$ & $\begin{array}{l}\text { Performance-based PSS, move to renewable } \\
\text { resources }\end{array}$ \\
\hline
\end{tabular}

a See Appendix B for detailed targeted value creation.

Table 3

Semi-structured interviews per case.

\begin{tabular}{|c|c|c|c|c|c|c|c|}
\hline \multirow[t]{2}{*}{ Case } & \multirow[t]{2}{*}{ Organization } & \multirow[t]{2}{*}{ Role } & \multirow[t]{2}{*}{ Interviewees } & \multicolumn{2}{|c|}{ Interview round } & \multirow{2}{*}{$\begin{array}{l}\text { Interview } \\
\text { context }\end{array}$} & \multirow[t]{2}{*}{ Duration } \\
\hline & & & & $\begin{array}{l}1 \\
\text { (exploration) }\end{array}$ & $\begin{array}{l}2 \\
\text { (validation) }\end{array}$ & & \\
\hline One & Heijmans & Initiator & Director Strategy \& Innovation & $\mathrm{x}$ & & FTF & $60 \mathrm{~min}$ \\
\hline \multirow[t]{2}{*}{ Niaga } & DSM-Niaga & Initiator & General Manager & $\mathrm{x}$ & & FTF & $20 \mathrm{~min}$ \\
\hline & Niaga & & Chief Technology Officer & $\mathrm{x}$ & & FTF & $75 \mathrm{~min}$ \\
\hline \multirow[t]{2}{*}{ Futureproof } & Kingspan & Initiator & Commercial Director & $\mathrm{x}$ & & FTF & $75 \min$ \\
\hline & Kingspan & & Bus. Manager Kingspan Energy & & & FTF & $60 \mathrm{~min}$ \\
\hline \multirow[t]{6}{*}{ Ecor Circular Friesland } & Ecor & Initiator & CEO Circular Economy Benelux & $\mathrm{x}$ & $\mathrm{x}$ & FTF & $75 \min$ \\
\hline & Reg. Inv. \& Devt. & Investor \& networking & Strategy \& Corporate Affairs & & $\mathrm{x}$ & FTF & $15 \mathrm{~min}$ \\
\hline & Agency. & Application \& supply & CE Bus. Development & & $\mathrm{x}$ & FTF & $60 \mathrm{~min}$ \\
\hline & Waste coll. \& processor & Application & Foreign Direct Investment Agri \& & & $\mathrm{x}$ & Phone & $60 \mathrm{~min}$ \\
\hline & Builder & & Food & & $\mathrm{x}$ & Phone & $45 \mathrm{~min}$ \\
\hline & & & $\begin{array}{l}\text { General Director } \\
\text { R\&D Manager }\end{array}$ & & & Phone & $60 \mathrm{~min}$ \\
\hline \multirow{3}{*}{$\begin{array}{l}\text { Food-for-Feed-for- } \\
\text { Food }\end{array}$} & Nijsen-Granico & Initiator & General Director & $\mathrm{x}$ & $\mathrm{x}$ & FTF & $75 \mathrm{~min}$ \\
\hline & Env. NGO & Certification & Project Employee & & $\mathrm{x}$ & Phone & $45 \mathrm{~min}$ \\
\hline & Municipality & $\begin{array}{l}\text { networking } \\
\text { Farmer support }\end{array}$ & Policy Officer Sustainability & & & FTF & $60 \mathrm{~min}$ \\
\hline Kipster & Kipster & Initiator & Founding Partner & $\mathrm{x}$ & & FTF & $60 \mathrm{~min}$ \\
\hline $\begin{array}{l}\text { Philips New } \\
\text { Karolinska }\end{array}$ & Philips Healthcare & Supplier & Program Manager & $\mathrm{x}$ & & Skype & $30 \mathrm{~min}$ \\
\hline BeeBanking & Stroom The Hague & Initiator & Head Project Office & $\mathrm{x}$ & & FTF & $60 \mathrm{~min}$ \\
\hline Thuisbaas & Thuisbaas & Initiator & Director & $\mathrm{x}$ & & Phone & $60 \mathrm{~min}$ \\
\hline
\end{tabular}

We applied focused sampling in grounded theory (Breckenridge, 2009; Charmaz, 2014; Glaser, 1978), which resulted in the selection of two cases wherein stakeholder alignment in the value network was particularly critical. Taking the firm's perspective of the network as the starting point, additional data was collected directly from collaboration partners in the network through site visits, expert consultations, participatory observation, and interviews. The questions focused on stakeholder alignment at normative, instrumental and strategic dimensions, and how alignment was facilitated through exploring, brokering and implementing boundary changes in the value network.

\subsection{Data analysis}

In the first empirical inquiry, discovery memos were written per data source, reflecting on emerging issues, and exploration of dimensions and linkages between the concepts of SBMI, value creation, collaboration and boundary work. Subsequently data was inductively and descriptively coded line-by-line, using open coding. The multitude of codes (e.g. changing role, responsibilities, new 
process) were allocated to themes such as innovation type, hybridization, value definition, value proposition, values-based innovation, partners and partner selection, aim of collaboration, innovation phases, critical moments, success and failure factors, novelty of business model, boundary conditions, and learnings. We found central themes related to boundary work, such as the content of boundary work (e.g. understandings of value, envisioned roles and activities) and the process of boundary work (e.g. the challenges to facilitate this process), as well as different types of boundaries, presented in section 4.1. Additional literature review and discussions amongst the authors led to a more detailed boundary work framework, showing that SBMI involves alignment on three dimensions, with boundary work consisting of exploring boundaries \& boundary dissonance, brokering boundaries and implementing boundary change. This resulted in improved themes and related interview questions.

In the second empirical inquiry, we focused data collection and coding (Breckenridge, 2009; Charmaz, 2014; Glaser, 1978) and deductively coded the field recordings and interview transcripts to validate the boundary work framework (Section 4.2). This highly iterative process between data collection, data analysis and theoretical categorization fits theory building from case studies as defined by Eisenhardt (1989) and Eisenhardt and Martin (2000). Quotes presented in this paper are in English, yet it must be noted that they have been translated from the original Dutch, except for Philips New Karolinska.

\section{Results}

\subsection{Exploratory interviews}

This section describes the results of the exploratory interviews on the role of organizational boundary changes, multi-stakeholder collaboration and boundary work in SBMI.

\subsubsection{Organizational boundary changes}

Empirical observations of this section aimed to explore how, if at all, organizations change boundaries in SBMI, and, subsequently, what these boundaries could exactly entail. We found possible boundary changes of initiating organizations as well as by actors in the value network, the latter being promoted during the innovation process (Table 4).

Boundary changes in the initiating organization were observed in all cases, referring to extended understandings of value, novel value propositions, business models and roles as, for example, a system integrator or sustainability steward (see also Appendix B for a more elaborate overview). The cases show particularly that SBMI required actors to take up new roles - for instance, from being a building company to acting as system integrator (Heijmans One) or from being a waste collector to delivering waste (Ecor Circular Friesland). This suggests organizational changes with regard to efficiency (new tasks) and competence (new resources required for new task).

Our nine cases confirm that companies attempt to innovate sustainable business models by engaging in novel collaborations. However, the inclusivity of actors from diverse domains differs between the cases. Cases initiated by governmental organizations and NGOs include civil society and/or sustainability funds in multiple roles (such as financers, customers, ambassadors) next to public partners (as financers and ambassadors) and private partners (as suppliers). Companies tend to focus on actors in the private domain in roles as financers, suppliers and customers. In cases 2 and 3, new partners were intentionally searched for in different sectors to bypass industrial lock-in after failing to collaborate with partners in conventional sectors. The interviewees mentioned required boundary change from customers, competitors, suppliers, financers, governmental and indirect stakeholders, although implementation of boundary change in the value network was not self-evident. Organizational boundary changes were most apparent in cases with circular business models (case 2,4,5), as illustrated in Nijsen/Granico:

Previously, our customer was the pig farmer [...] to we sold [pig feed], as a simple value chain story: we converted raw materials into a product which we sold to the next link of the value chain: the pig farmer [...] Now, my customer is the retailer, and my current customer [the pig farmer] becomes my strategic partner" (General Director Nijsen/Granico, interview 19-05-2017)

As will be explored below, not all value propositions were sufficient to implement boundary change. An extended overview of the main collaboration partners, partner novelty and reasons for collaborating can be found in Appendix B.

\subsubsection{Multi-stakeholder boundary exploration}

We found that exploration of boundaries occurs throughout the innovation process: with increasing complexity of the value network, more time was required for boundary exploration. For the initiating companies, it was not always clear whether actor boundaries were aligned. In cases where initially shared understandings of value were perceived, dissonance emerged in later innovation stages, when commitment for changing activities was requested from collaboration partners. This happened, for example, in Kingspan Futureproof:

"We now know that a sales pitch in the beginning always sounds good, it literally opens doors, but once we are in the farm house, sitting at "the farmer's table" all kind of practical difficulties surface as hurdles" (Commercial director Kingspan FutureProof, interview 02-05-2017)

Boundary dissonance in the firm's value network was perceived in seven cases and on multiple boundary dimensions (Table 5). The main boundary dissonance mentioned were misaligned business model elements, narrow understandings of value and responsibilities, and legal boundaries. Boundary dissonance was not in all cases critical for business model innovation. However, it did influence the value created. For example, the Niaga business model could be implemented with a mere economic understanding of value, as the technology reduces costs throughout the value chain through increased production and installation efficiency. However, alignment around the importance of sustainability was required to close the loop and internalize the envisioned externality of carpet waste.

The previous section showed that boundaries were not always clear and were explored during the innovation process. We found that simultaneously, boundaries themselves were subject to evolvement through extension, narrowing and redesign, as organizations learned about the implications of the innovation for their business model. An example is Kingspan Futureproof, in which energy companies enhanced their activities on the instrumental boundary dimension twice by pre-financing farmer projects:

"The project accelerated when the energy company said 'I would like to pre-finance part of the investment'. Well, that is very interesting, so we said: can we come to an agreement on this, to which they said yes, so we made a framework agreement based on general parameters, as a stepping stone to a mutually signed contract with descriptions and specifications, which would happen in a pilot sphere. Then, they said 'we will buy your stuff, changing 
Table 4

(Promoted) boundary change of the initiating organization and actors in the value network, mentioned by the interviewees.

\begin{tabular}{|c|c|c|c|c|c|}
\hline Case & Actor & Original boundary & (Promoted) boundary change & $\begin{array}{l}\text { Interpretation of } \\
\text { organizational boundary } \\
\text { type }\end{array}$ & $\begin{array}{l}\text { Promoted boundary } \\
\text { implemented? }^{\mathrm{a}}\end{array}$ \\
\hline Heijmans One & Heijmans & Building company & $\begin{array}{l}\text { System integrator, adding value through technology, innovation, } \\
\text { sustainability } \\
\text { Temporary pre-financer }\end{array}$ & $\begin{array}{l}\text { Identity, competence, } \\
\text { efficiency }\end{array}$ & Yes \\
\hline Niaga & $\begin{array}{l}\text { DSM-Niaga } \\
\text { Carpet } \\
\text { producer }\end{array}$ & $\begin{array}{l}\text { n.a. } \\
\text { Purchase license, product and sell carpet to retail }\end{array}$ & $\begin{array}{l}\text { Resource steward, responsible for transforming materials without ownership, } \\
\text { extended responsibility towards end-consumer } \\
\text { Retain and remanufacture carpets }\end{array}$ & $\begin{array}{l}\text { Identity, competence, } \\
\text { efficiency } \\
\text { Competence, efficiency }\end{array}$ & $\begin{array}{l}\text { Yes } \\
\text { No }\end{array}$ \\
\hline $\begin{array}{l}\text { Kingspan } \\
\text { Futureproof }\end{array}$ & $\begin{array}{l}\text { Kingspan } \\
\text { Farmer } \\
\text { Subcontractor } \\
\text { Banks } \\
\text { Energy } \\
\text { company } \\
\text { Farmer- } \\
\text { relations } \\
\text { Government } \\
\text { Government }\end{array}$ & $\begin{array}{l}\text { Sales of roof and facade panels } \\
\text { Requests service/product on contract-basis } \\
\text { Responds to request for service } \\
\text { Bank loans to farmer } \\
\text { Separate banking groups } \\
\text { Energy company receives solar electricity } \\
\text { Accountant, professional associations, family, friends } \\
\text { focus on economic value, risk aversion } \\
\text { Asbestos and solar separately, temporarily financed } \\
\text { Limited possibility for roof ownership }\end{array}$ & $\begin{array}{l}\text { Integrated stable improvement } \\
\text { Temporary pre-financer to scale up Long-term commitment as subcontractor } \\
\text { Emerging as customer and organizing sales } \\
\text { Emerging as competitor of the financing energy company } \\
\text { Integrative financing of banking groups } \\
\text { Pre-financer using solar electricity as payment } \\
\text { Enhance understanding of value, long-term view } \\
\text { Maintain financing and couple themes } \\
\text { Fit legislation to purpose }\end{array}$ & $\begin{array}{l}\text { Competence, efficiency } \\
\text { Efficiency } \\
\text { Identity, competence, } \\
\text { efficiency } \\
\text { Efficiency } \\
\text { Efficiency } \\
\text { Identity, competence, } \\
\text { efficiency } \\
\text { Competence } \\
\text { Competence, efficiency } \\
\text { Efficiency }\end{array}$ & $\begin{array}{l}\text { Yes } \\
\text { Occasionally } \\
\text { Yes } \\
\text { Yes, unintended } \\
\text { Occasionally } \\
\text { Occasionally } \\
\text { Occasionally } \\
\text { No } \\
\text { No }\end{array}$ \\
\hline $\begin{array}{l}\text { Ecor Circular } \\
\text { Friesland }\end{array}$ & $\begin{array}{l}\text { Ecor } \\
\text { Gardener } \\
\text { Waste } \\
\text { collector } \\
\text { Building } \\
\text { companies } \\
\text { Housing } \\
\text { corporation }\end{array}$ & $\begin{array}{l}\text { n.a. } \\
\text { Gardening company taking care of greenery } \\
\text { Collecting private and public waste } \\
\text { Producing and installing building materials } \\
\text { Focus on efficient materials }\end{array}$ & $\begin{array}{l}\text { Resource steward, extended responsibility towards end-consumer } \\
\text { Temporary pre-financer } \\
\text { Deliver waste streams, use novel applications next to gardening } \\
\text { Funnel and deliver waste streams } \\
\text { Use novel materials and applications } \\
\text { Focus on sustainable materials }\end{array}$ & $\begin{array}{l}\text { Identity, competence, } \\
\text { efficiency } \\
\text { Identity, competence, } \\
\text { efficiency } \\
\text { Competence, efficiency } \\
\text { Competence, efficiency } \\
\text { Competence }\end{array}$ & $\begin{array}{l}\text { Yes } \\
\text { No } \\
\text { No } \\
\text { No } \\
\text { No } \\
\text { No }\end{array}$ \\
\hline $\begin{array}{l}\text { Food-for- } \\
\text { Feed-for- } \\
\text { Food }\end{array}$ & $\begin{array}{l}\text { Producer raw } \\
\text { materials } \\
\text { Nijsen/ } \\
\text { Granico } \\
\text { Pig } \\
\text { entrepreneur } \\
\text { Retail } \\
\text { NGO } \\
\text { Butcherer } \\
\text { Municipality }\end{array}$ & $\begin{array}{l}\text { Sourcing raw materials } \\
\text { Pig feed producer sourcing from food waste streams and } \\
\text { (global) raw materials } \\
\text { Purchases animal feed from focal business } \\
\text { Retail purchases meat from butcher, price-focused, } \\
\text { transactional, short-term relation } \\
\text { Campaigning against retailers to increase animal welfare } \\
\text { and change environmental impact } \\
\text { Butcher manufactures in bulk } \\
\text { Promoting societal values through legislation and control }\end{array}$ & $\begin{array}{l}\text { Redundant } \\
\text { Pig feed producer sourcing only from food waste streams, offering sustainable } \\
\text { food concepts, system integrator } \\
\text { Strategic partner in sustainable pig keeping \& part of entrepreneurs } \\
\text { redundant } \\
\text { Emerging as strategic partner and direct supplier for animal feed, } \\
\text { sustainability focus next to price focus, long-term } \\
\text { Collaborating with retail to enhance sustainable food and influence customer } \\
\text { Butcher separates focal meat } \\
\text { Early facilitation and promotion of societal values }\end{array}$ & $\begin{array}{l}\text { Identity, competence, } \\
\text { efficiency } \\
\text { Identity, competence, } \\
\text { efficiency } \\
\text { Competence, efficiency } \\
\text { Competence, efficiency } \\
\text { Identity, competence, } \\
\text { efficiency } \\
\text { Efficiency } \\
\text { Efficiency }\end{array}$ & $\begin{array}{l}\text { Envisioned } \\
\text { Envisioned } \\
\text { No } \\
\text { No } \\
\text { Yes } \\
\text { No } \\
\text { Yes }\end{array}$ \\
\hline Kipster & $\begin{array}{l}\text { Kipster } \\
\text { Retail }\end{array}$ & $\begin{array}{l}\text { n.a. } \\
\text { Transactional, short-term, price-based contract }\end{array}$ & $\begin{array}{l}\text { Most sustainable egg producer, reversed thinking } \\
\text { Relational, long-term, value-based contract }\end{array}$ & Identity, competence & $\begin{array}{l}\text { Yes } \\
\text { Yes }\end{array}$ \\
\hline $\begin{array}{l}\text { Philips New } \\
\text { Karolinska }\end{array}$ & $\begin{array}{l}\text { Philips } \\
\text { Competitor }\end{array}$ & $\begin{array}{l}\text { Sell and service of healthcare equipment } \\
\text { Delivers healthcare to hospitals }\end{array}$ & $\begin{array}{l}\text { Extended, full responsibility for (competitor) equipment performance } \\
\text { Sub-supplier to Philips }\end{array}$ & $\begin{array}{l}\text { Competence, efficiency } \\
\text { Efficiency }\end{array}$ & $\begin{array}{l}\text { Yes } \\
\text { Yes }\end{array}$ \\
\hline $\begin{array}{l}\text { BeeBanking } \\
\text { Thuisbaas }\end{array}$ & $\begin{array}{l}\text { Stroom } \\
\text { Thuisbaas } \\
\text { Supplier } \\
\text { House-owners }\end{array}$ & $\begin{array}{l}\text { Art institute with conventional, public financing } \\
\text { n.a. } \\
\text { Install and sell equipment } \\
\text { Purchase of e.g. solar panels, isolation }\end{array}$ & $\begin{array}{l}\text { Collaborate with civil society for financing } \\
\text { Extended responsibility for cost-neutrality, reversed thinking (possibilities } \\
\text { based on average energy costs) } \\
\text { Integrative approach, extended responsibility } \\
\text { Commitment for integrated house retrofitting }\end{array}$ & $\begin{array}{l}\text { Efficiency } \\
\text { Competence, efficiency } \\
\text { Competence, efficiency }\end{array}$ & $\begin{array}{l}\text { Yes } \\
\text { Yes } \\
\text { Occasionally } \\
\text { Occasionally }\end{array}$ \\
\hline
\end{tabular}

${ }^{a}$ At time of interview. 
Table 5

Boundary dissonance mentioned by interviewees.

\begin{tabular}{|c|c|c|c|}
\hline Boundary Dissonance Codes & $\begin{array}{l}\text { \# inter- } \\
\text { viewees }\end{array}$ & Case & Examples \\
\hline Short-term focus & 2 & Heijmans One & $\begin{array}{l}\text { Long-term focus ( } 30 \text { year) of lease companies is required for long product lifetimes, while they focus } \\
\text { on short term investments ( } 10 \text { year) }\end{array}$ \\
\hline Value chain approach & 2 & $\begin{array}{l}\text { Food-for-Feed- } \\
\text { for-Food }\end{array}$ & $\begin{array}{l}\text { Key-partners focus on value chain instead of ecosystems, imposing responsibility on the wrong actors } \\
\text { in the value network }\end{array}$ \\
\hline Limited feeling of urgency & 1 & $\begin{array}{l}\text { Kingspan } \\
\text { Futureproof }\end{array}$ & Actors, in particular customers, lack a sense of urgency for sustainability related issues \\
\hline $\begin{array}{l}\text { Limited consideration of } \\
\text { environmental and social value }\end{array}$ & 4 & $\begin{array}{l}\text { Niaga } \\
\text { Kingspan } \\
\text { Futureproof } \\
\text { Ecor Circular } \\
\text { Friesland }\end{array}$ & $\begin{array}{l}\text { Selection of materials is mainly about the fractional price differences/advantages (e.g. polypropylene } \\
\text { vs. polyester) and not about product take back } \\
\text { Most clients are driven by a direct solution to their specific problem(s) instead of long-term benefits } \\
\text { Circular Economy seems to focus mostly on the economy now, while it is also about different } \\
\text { consciousness and behavior }\end{array}$ \\
\hline Lack of integrated approach & 1 & $\begin{array}{l}\text { Kingspan } \\
\text { Futureproof }\end{array}$ & $\begin{array}{l}\text { Separate actors focus on their own propositions (solar financing, asbestos removal financing) instead } \\
\text { of coupling themes and finances }\end{array}$ \\
\hline Business model & 5 & Heijmans One & Multiple innovations are required from external partners, particularly financing models \\
\hline Limited responsibility & 3 & $\begin{array}{l}\text { Food for Feed } \\
\text { for Food } \\
\text { Thuisbaas }\end{array}$ & $\begin{array}{l}\text { Key-partners refuse to take responsibility for their role in the SBMI process } \\
\text { A lack of responsibility for the results ended several collaborations }\end{array}$ \\
\hline Legal & 3 & $\begin{array}{l}\text { Kingspan } \\
\text { Futureproof } \\
\text { Niaga }\end{array}$ & $\begin{array}{l}\text { Legislation is not fit for the purpose of shared ownership (of roofs) and material take back } \\
\text { Legislation approves deviation from pure materials, which obstructs remanufacturing }\end{array}$ \\
\hline
\end{tabular}

their tune even to: 'we want to do the projects of you lock stock and barrel"' (Commercial director Kingspan FutureProof, interview 02-05-2017).

However, the energy company narrowed its boundary after being disappointed in piloting, causing a pause to the SBMI process:

"The same party actually became an inhibiting factor, after realizing mmh we have to do more than anticipated (negotiated for) and after discovering that the projects involve much higher risks for us, having to do with the creditworthiness of the sector. So, that is now again an inhibiting factor. So actually the second success factor, the second accelerator, changed into a brake, the first real brake we encountered and a formidable one too" (Commercial director Kingspan FutureProof, interview 02-05-2017).

The initiating business responded to this boundary dissonance through pre-financing, while searching for new partners and trying to find alternative business model options. Temporary boundary change happened in response to limited boundary alignment, taking up a novel role as pre-financer (cases 1, 2, 3, 4) or compromising on value creation (e.g. a less circular business model, as shown in DSM-Niaga). This suggests that boundary maintenance or change affects value creation and might lead to terminating the collaboration.

\subsubsection{Boundary spaces, objects and spanners}

Empirical inquiry aimed to explore in what ways boundary work activities took place. We found that a boundary organization external to the actors was absent in all cases. Instead, the initiating organizations themselves conducted boundary brokering, except for New Karolinska. Boundary brokering happened rather ad-hoc, and in the majority of cases, organizations met bilaterally instead of in a joint boundary space. Only Ecor and New Karolinska took a more systematic approach by facilitating joint meetings. In New Karolinska, boundary brokering started from a joint boundary space initiated by the Stockholm County Council:

"Stockholm County Council ran this process as a competitive dialogue, where they invited Philips, Siemens and GE, to many many different meetings, where we discussed different kind of matters, issues, where also a lot of proposals and thinking were done"
(Program Manager Philips New Karolinska, interview 22-062017)

Boundary objects were used to test commitment, support interaction and negotiate tensions. For example, DSM-Niaga mentioned that the joint creation of the total value model (including value beyond the traditional partners and return value) helped to enhance the importance of establishing take-back processes. The concreteness of the objects and its scope of interacting actors differed. Typically boundary objects transformed from abstract and open for adaption in early innovation phases (such as sketches, drawings, mockups) to concrete, rather fixed objects in later innovation phases (such as place making, piloting and calculation sheets). The use and development of boundary text was mentioned by eight cases (Table 6).

\subsubsection{Discussion on exploratory findings}

Resulting from this exploratory study on boundary work practices, we understand the role of boundary work in SBMI as the practices to create, shape and disrupt organizational boundaries in three highly iterative boundary work activities: (i) exploring boundaries and boundary dissonance, (ii) brokering boundaries and (iii) implementing boundary change.

Firstly, exploring the current state of boundaries in the value network aims for a better understanding of the external context and illuminates (critical) boundary dissonance between focal organizations and their stakeholders (Matos and Silvestre, 2013). Freudenreich et al. (2019) suggest that organizational transformation processes may be unlocked when the focal company and its stakeholders purposefully explore similarities and differences for joint value creation by examining what each stakeholder group considers to be valuable in relation to sustainability.

Secondly, boundary brokering activities are relevant to challenge, negotiate and reconcile critical boundary dissonance. Boundary brokering involves discussions on where organizational boundaries are to be established, while accommodating individual value frames and interests through boundary texts, objects and people (Carlile, 2002; O'Mahony and Bechky, 2008).

Finally, the nature and dimension of implementing boundary change is expected to evolve during the process, as the different parties gain knowledge about (the feasibility of) required boundary 
Table 6

Boundary objects mentioned by the interviewees.

\begin{tabular}{|c|c|c|c|}
\hline Case & Boundary text & Boundary objects and examples & \\
\hline Heijmans One & $\begin{array}{l}\text { paused landscape, put paused } \\
\text { landscapes on play, generation Y, } \\
\text { movable, mobile single home, movable } \\
\text { single-person home, design }\end{array}$ & pictures, placemaking & $\begin{array}{l}\text { Coupling paused landscapes with generation Y problem of } \\
\text { affordable housing, and placing mobile homes as objects at } \\
\text { paused landscapes to attract attention and pilot the envisioned } \\
\text { benefits }\end{array}$ \\
\hline DSM-Niaga & $\begin{array}{l}\text { old world, new world, turning point, } \\
\text { responsibility, circularity, mono- } \\
\text { material }\end{array}$ & $\begin{array}{l}\text { sketches, black box as mockup, } \\
\text { shared calculation sheets }\end{array}$ & $\begin{array}{l}\text { Coupling limited responsibility for value of the 'old world' with } \\
\text { extended responsibility of the 'new world', and collectively } \\
\text { create the value model to convince partner's managers and } \\
\text { create trust }\end{array}$ \\
\hline Kingspan Future-proof & $\begin{array}{l}\text { sustainability, integrated, financing } \\
\text { sustainability }\end{array}$ & infographic & $\begin{array}{l}\text { Using words such as 'integrated financing' to couple asbestos to } \\
\text { renewable energy. An infographic was used to illustrate } \\
\text { potential environmental impact to high-level stakeholders }\end{array}$ \\
\hline Ecor Circular Friesland & equity, economy, ecology & true cost modelling & $\begin{array}{l}\text { Adopt collective True Cost Modelling based on equity, economy } \\
\text { and ecology concepts }\end{array}$ \\
\hline Food-for-Feed-for-Food & $\begin{array}{l}\text { circular food concept, front-door, } \\
\text { backdoor, circular pig, Pikster, } \\
\text { ambition, integrally sustainable, }\end{array}$ & Project proposal, blockchain & $\begin{array}{l}\text { Using a project proposal as object of discussion in the } \\
\text { explorative phase. Blockchain is considered a possible virtual } \\
\text { trust object in implementation phase }\end{array}$ \\
\hline Kipster & $\begin{array}{l}\text { animal welfare, sustainability, } \\
\text { partnership }\end{array}$ & sketches & Using a 3D sketch in early phases to convince retail \\
\hline Philips New Ka-rolinska & not mentioned & room drawings, site visits & $\begin{array}{l}\text { Collective meetings, discussion and site visits based on every } \\
\text { room, using drawings to cover the full room equipment }\end{array}$ \\
\hline Bee-Banking & pollination, life, bees, creating value & saving booklets, art object & $\begin{array}{l}\text { Using saving booklets for financers (mostly civil society) } \\
\text { conveying the message of the project and amplifying partner's } \\
\text { contribution to life. Spreading the message through a physical } \\
\text { art objects (Honey Banks) in urban spaces }\end{array}$ \\
\hline Thuisbaas & reliable, energy-neutral, affordable & piloting & $\begin{array}{l}\text { Piloting affordable, reliable and energy-neutral housing, leading } \\
\text { to ending of collaborations as these expectations were not met }\end{array}$ \\
\hline
\end{tabular}

change and about value creation and appropriation. Any required boundary change thus relates to how it is perceived as 'fair' or 'effective' and 'efficient' (Bocken et al., 2019) and how stakeholder interests and expectations are being met. This can have wider implications when boundary changes lead to a fundamental change in the operation of sectors.

\subsection{Deeper analysis of boundary work}

This section presents the results of the interviews with a wider set of stakeholders involved in the boundary work activities for the cases of Food for Feed for Food and Ecor Circular Friesland. We examine the topics for discussion and negotiation in relation to boundary change amongst business actors and non-business actors.

\subsubsection{Exploring boundaries and boundary dissonance}

In the case of Nijsen/Granico the external actors are the owner of Kipster (case 6), an environmental NGO, and a municipality, of which the last two are new to Nijsen/Granico. The respondents agreed on the general idea (vision) of using food waste to feed pigs. They also agreed on the principles of 1) using circular and regionally sourced feed, 2) improving animal welfare and an environmentally friendly stable, and 3) use of sustainable logistics based on electric vehicles. Discussed value capture elements included the elimination of uncertainties regarding price, volume and timespan of production, but achieving this will require changes outside the present partnership. From retailers, it requires a partnership that extends the traditional transactional focus towards a relational, longer-term contract. It also requires cooperation from framers and acceptance by consumers, actors who are currently not part of the partnership (incomplete value network).

In the case of ECOR Friesland, a broad vision of a circular Friesland was agreed to by a wide group of actors, Roles and responsibilities were discussed together with complexities in the form of technical requirements for waste streams and applications, potential material flows, applications and markets, potential customer value propositions, appropriate business models (cooperation and community-building or individual business model development). Direct and indirect value using True Cost Modeling surfaced as a model for evaluating options and coordinating decisions. Ecor is in charge of this. NOM and Circular Friesland Foundation agreed to play role in searching for potential collaboration partners.

\subsubsection{Brokering boundaries}

Nijsen/Granico is in the lead for orchestrating the network of food waste for pigs. In principle, meetings are in groups, which the interviewees considered important in the early stages, but there are also informal, bilateral meetings between partners (for example between Nijsen/Granico and Kipster. All interviewees mentioned that they feel this way of collaborating is sufficient to express their interests and perspectives. However, the absence of farmers, traders, butchers, retailers and end-consumers means that their interests are being considered only through the eyes of the other actors. The boundary arrangement is incomplete, something which may jeopardise the SBMI process.

\subsubsection{Implementing boundary change}

Nijsen/Granico moved from a value chain to a value network focus, it considers societal and environmental values next to economic values and plays a strategic role as system coordinator, developing sustainable meat concepts. Novel activities on the instrumental dimension are to be implemented in concert with partners' boundary changes. To date, boundary change of key partners, several of which who show critical boundary dissonance, is absent. In the Ecor Friesland case, Ecor and NOM are actively engaged in activities in networking, facilitating and promoting. Supply and application partners are presently exploring value propositions and business model opportunities, as well as technical requirements. Both cases attest to the difficulty of achieving boundary change on multiple dimensions for a wide set of actors. 


\section{Discussion \& conclusion}

\subsection{Discussion}

This study explores the role of boundary work as a novel perspective on SBMI, consisting of:

1) different types of organizational boundaries and boundary changes within and across organizations

2) three iterative boundary work phases as processes for multistakeholder alignment; exploring boundaries and boundary dissonances, brokering boundaries in spaces, texts, objects and people, and implementing boundary changes

3) the role of boundary spanners and boundary arrangements.

As an agenda-setting paper, we make three contributions. First, we specify the different types of organizational boundaries and boundary changes relevant for SBMI. The literature falls short in a concrete definition of organizational boundaries for SBMI, or what these boundaries look like in practice. This study complements previous studies on the role of boundary spanning in SBMI (e.g. Brehmer et al., 2018) by demonstrating that organizations change boundaries of identity, competence and efficiency through normative, strategic and instrumental alignment, relating to dimensions known in SBMI literature (Breuer and Lüdeke-Freund, 2017; Stubbs and Cocklin, 2008). This is relevant as we found that boundary changes of network actors provides the opportunity to leverage or impede value creation as actors maintain, create and adapt organizational boundaries along the process. This was illustrated in DSM-Niaga, which requires boundary changes of producers and retailers in order to be able to return carpet streams and capture the envisioned value. The iterative character of boundary changes was illustrated in Kingspan's collaboration with their investor, whose boundaries changed multiple times, thereby affecting the implementation of the business model. Hence we contributed to the SBMI literature by exploring value propositions for a broad range of actors, consisting of immediate values such as cost reduction, unburdening and convenience (core-benefits) as well as rather diffuse benefits such as long-term health, local production or environmental improvements (co-benefits) (Baldassarre et al., 2017; Patala et al., 2016). While this study is a first attempt to identify organizational boundaries and boundary changes in SBMI, further research could improve our understanding of organizational boundaries and search for patterns of boundary changes, as well as the impact of boundary changes on the SBMI process.

Second, the cases pointed at three phases of boundary work; exploring boundaries and boundary dissonances, brokering boundaries, and implementing boundary changes. The cases showed that these activities happen in collaboration with nonmarket actors, such as municipalities, NGOs and policy-makers. This confirms that SBMI requires alignment beyond the value chain, which is known from literature on innovation networks (Bouwman et al., 2008; Ojasalo, 2008) and networked enterprises (Solaimani and Bouwman, 2012). A boundary work perspective adds that non-market actors are sometimes involved only during the process of innovation, e.g. for brokering, accelerating or value enhancing purposes. The boundary work activities led to novel multi-stakeholder networks, based on a shared understanding of value rather than traditional sectors, as illustrated in DSM-Niaga bypassing carpet manufacturers, and Kingspan Futureproof bypassing asbestos removers. These findings contribute to the cross-sectoral collaboration literature by eliciting the (novel) positioning of partners, as well as the intersection of domains
(Austin and Seitanidi, 2012b; Harrington and Srai, 2016). Particularly in the circular economy cases, the slowing and closing of resource loops requires a high dimension of value network reconfiguration. The literature confirms that in these processes, understandings of retained and destroyed value along the product lifespan should be transformed into new value opportunities, and reversed logistics and take-back systems should be incorporated as activities (Achterberg et al., 2016; Witjes and Lozano, 2016). As a result, collaboration with partners at the end of the value chain, such as retailers and consumers, becomes increasingly important (Fischer and Pascucci, 2017), as was visible in DSM-Niaga, Nijsen/ Granico, Ecor and Philips New Karolinska. Circular economy models tend to focus on materials and resources (Geissdoerfer et al., 2017), while requiring boundary change throughout the value network including novel, roles, forms of partner contracting, legislation and knowledge generation (Kraaijenhagen et al., 2016). Additionally, further research is needed to investigate patterns of collaboration in the different boundary work phases, as well as the roles of different actors in these multi-stakeholder collaborations. Additionally, further research could inquire whether the boundary work perspective holds its relevance in circular business model innovation, as our research did not focus on circular economy specifically.

Third, a boundary work perspective led to the identification of boundary spanners, using objects and tools to learn about value creation, value appropriation and expectations of the actors involved, in order to ultimately align boundaries in their external network. This corresponds with the partnership literature on value frame fusion (Le Ber and Branzei, 2010a, 2010b) and value appropriation (Covey, 2006; Garcia-Castro and Aguilera, 2015) in crosssector interactions. The boundary spanner seems important because "people are bad at taking experiential worlds and other people's incentives seriously and learning about them" (Diepenmaat, 2018, p. 954). Assumptions about needs and interests need to be checked and collectively ascertained, as related boundaries have been found to be diffuse, ambiguous, and changing along the innovation process, based on expectations and experiences. Boundary texts and tools helped to keep the actors committed but in the end all network actors need to obtain material gains fitting with their mandate (government), missions (NGOs) and commercial interests. The literature on cross-sector collaboration emphasizes the complexity of partnerships between businesses, NGOs and public actors; among others due to conflicting institutional logics, interests and values (Ashraf et al., 2017; Jay, 2017). This makes it pertinent to explore partners' divergent interests, resources, motives and missions (Austin and Seitanidi, 2012a) and to fuse value frames to co-create value (Le Ber and Branzei, 2010a,b; Oskam et al., 2018). Most cases show that the focal business takes the initiative for boundary work and conducts boundary brokering activities to capture envisioned value. In Philips New Karolinska, external actors facilitated boundary work, which corresponds to the findings of Boons et al. (2016), who describe third-party brokering and collective learning as strategies for knowledge production in industrial symbiosis, as well as Smink et al. (2015), who point at the importance of boundary spanners to increase mutual understanding in renewable energy production. We found that boundary brokering may be present in the transfer of knowledge (e.g. for exchange of materials and applications), but may also be needed on higher dimensions (e.g. to discuss interests and understandings of value). This corresponds with knowledge transformation and translation processes mentioned by Carlile (2002), who recognize the importance of negotiating actor interests and trade-offs with a prominent role for shared artifacts and methods as boundary objects of knowledge transformation, such as 


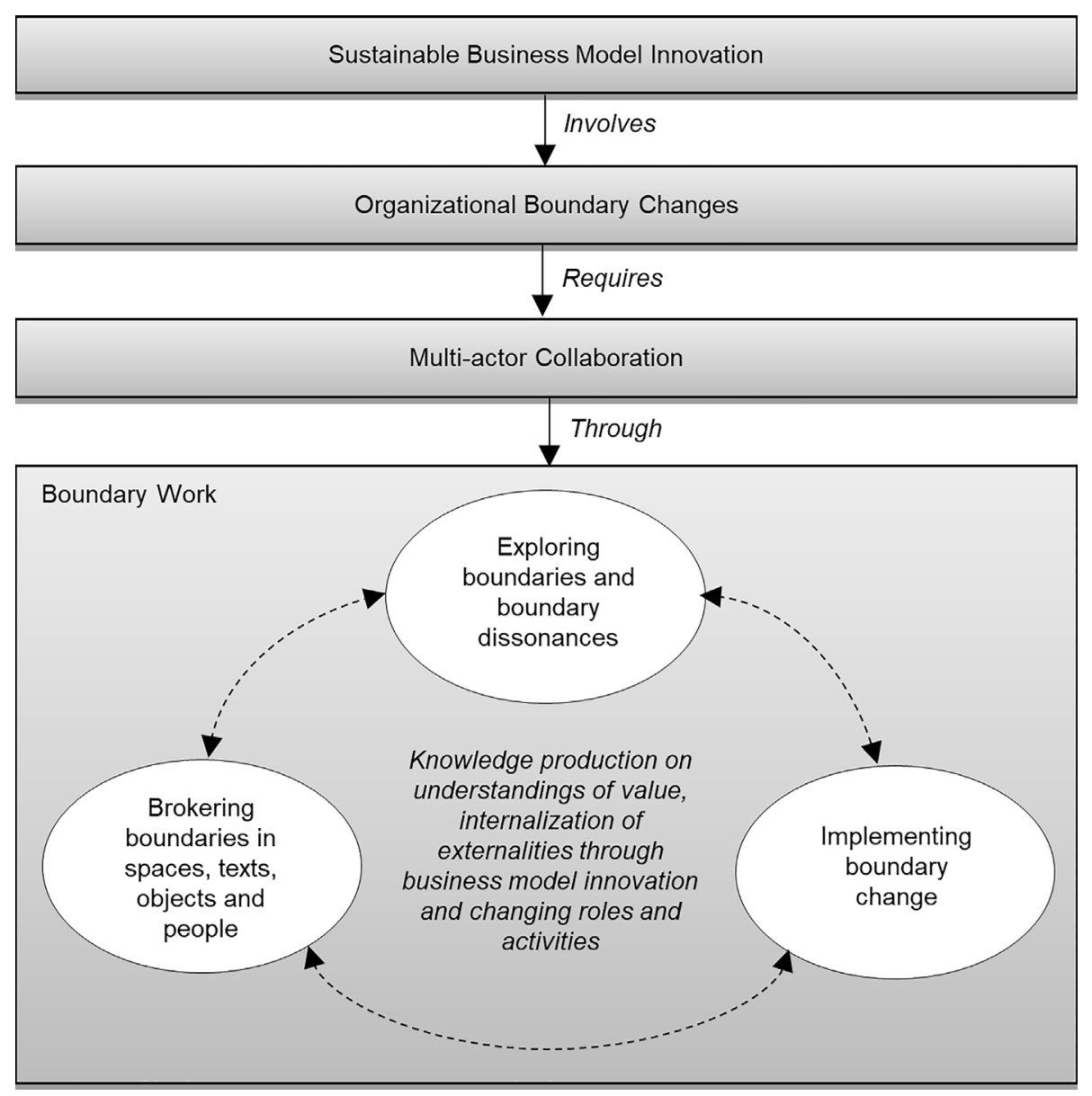

Fig. 1. Conceptual framework for Boundary Work in SBMI.

drawings and prototypes, to create willingness for boundary change. SBMI literature mentions participatory backcasting (Vergragt and Quist, 2011), joint visioning (Leising et al., 2018) and experimentation (Bocken et al., 2018, 2019; Brown and Vergragt, 2008) as strategies for knowledge production. This points at future research avenues to investigate the governance and brokering processes of boundary spanners in the different boundary work phases of SBMI, as well as the relations between boundary brokering practices and organizational boundary change.

Based on the exploratory findings, we consider boundary work in SBMI a valuable perspective to understand organizational boundaries and the process of boundary alignment in multistakeholder collaborations. As this is an exploratory study, a deeper analysis is needed to analyse all elements of the framework in-depth (visualized in Fig. 1). Wider applicability of the boundary work perspective could be useful in contexts where firm- and industry boundaries are increasingly blurred and boundary realignment is required, such as BMI for digital transformation. Finally, to make it useful for practice, further operationalization and instrumentation is needed in the form of new tools and methods for boundary work in SBMI to assist organizations in the creation and management of value networks for a sustainable or circular economy. We also want to note that system change cannot be organized in an entirely bottom-up way, but requires actions from governments, citizen groups and knowledge intermediaries. New value networks and experiments involving different actors play an important role in better understanding system barriers, as the basis for coordinated action. Tools and methods can support this process of multi-stakeholder experimentation.

\section{Conclusion}

This paper explored the role of organizational boundaries and boundary work in SBMI. We have found that SBMI involves organizational boundary changes related to normative, strategic and instrumental alignment. Boundary alignment in the value network is required, however difficult, due to collaboration with unfamiliar actors, interaction between the different organizational boundaries as well as external boundary changes. Three phases of boundary work activities are relevant for multi-stakeholder alignment: exploring boundaries and boundary dissonances; brokering boundaries; and implementing boundary change. This study provides avenues for future research on boundary work for SBMI.

\section{Acknowledgements}

We would like to thank the interviewees for their support and time made available for interviews. We also want to thank Henk Diepenmaat for providing valuable insights on the multistakeholder perspective and Aimée Kyffin for her language expertise.

Appendix A. Review of interlinkage between sustainable business models and value creation 


\begin{tabular}{|c|c|c|}
\hline & Business Model & Sustainable business model \\
\hline Value form & Value created and captured & $\begin{array}{l}\text { Value created and captured plus value absence, destroyed, missed or surplus, new value } \\
\text { opportunities }\end{array}$ \\
\hline $\begin{array}{l}\text { Bocken et al. } \\
\text { (2013) }\end{array}$ & Value created and captured & Value created and captured plus value destroyed, missed or surplus, new value opportunities \\
\hline $\begin{array}{l}\text { Bocken et al. } \\
\quad(2015)\end{array}$ & & Value forms; social, economic, ethical \\
\hline $\begin{array}{l}\text { Evans, Fernando, } \\
\text { et al. }(2017 \mathrm{a}, \mathrm{b})\end{array}$ & Value created and captured & $\begin{array}{l}\text { Value created and captured plus value absence, surplus, destroyed, missed, new value } \\
\text { opportunities }\end{array}$ \\
\hline Value priority & Economic first & Societal \& environmental value first or equal to economic value \\
\hline $\begin{array}{l}\text { Freeman (1984) } \\
\text { Schaltegger et al. } \\
\quad(2016)\end{array}$ & $\begin{array}{l}\text { Economic first } \\
\text { Economic first }\end{array}$ & $\begin{array}{l}\text { Economic through societal \& environmental first } \\
\text { Economic through societal \& environmental first }\end{array}$ \\
\hline $\begin{array}{l}\text { Stubbs and Cocklin } \\
\text { (2008) }\end{array}$ & Maximize shareholder value & No prioritizing of stakeholders \\
\hline Value horizon & Direct, short- or medium- term & Direct, short- or medium- term plus indirect, long-term \\
\hline $\begin{array}{l}\text { Freeman (1984) } \\
\text { Krantz (2010) } \\
\text { Madden (2017) } \\
\text { Stubbs and Cocklin } \\
\quad(2008)\end{array}$ & Direct, short- or medium- term & $\begin{array}{l}\text { Long-term } \\
\text { The entire life cycle } \\
\text { Direct- short- or medium- term plus long-term, future generations } \\
\text { Longer-term }\end{array}$ \\
\hline Value created & (refined) shareholder value & Value for the common good \\
\hline $\begin{array}{l}\text { Dyllick and Muff } \\
\text { (2016) }\end{array}$ & (refined) shareholder value and/or triple bottom line & Value for the common good \\
\hline $\begin{array}{l}\text { Lüdeke-Freund } \\
\text { (2010) }\end{array}$ & & Private/customer and public benefits \\
\hline Madden (2017) & & Environment \\
\hline $\begin{array}{l}\text { Stubbs and Cocklin } \\
\text { (2008) }\end{array}$ & Maximize (refined) shareholder value & All stakeholders on the organizational \& socioeconomic level \\
\hline $\begin{array}{l}\text { Schaltegger et al. } \\
\text { (2016) }\end{array}$ & Organizational value & Organizational + Social and ecological value \\
\hline Value proposition & Customer value & Sustainable customer value and co-benefits through value for society \& environment \\
\hline $\begin{array}{l}\text { Bocken et al. } \\
\quad(2013)\end{array}$ & Customer & Customer, other stakeholders, society, environment \\
\hline Chesbrough (2010) & Users & \\
\hline $\begin{array}{l}\text { Osterwalder and } \\
\quad \text { Pigneur (2010) }\end{array}$ & Customer & \\
\hline Richardson (2008) & Customer & \\
\hline Teece $(2010)$ & Customer, business & \\
\hline \multicolumn{3}{|l|}{$\begin{array}{l}\text { Customer value } \\
\text { proposition }\end{array}$} \\
\hline $\begin{array}{l}\text { Bocken and } \\
\quad \text { Allwood (2012) }\end{array}$ & Customer value & Sustainable customer value through offering and value for society \& environment \\
\hline $\begin{array}{l}\text { Boons and Lüdeke- } \\
\text { Freund (2013) }\end{array}$ & Customer interface & $\begin{array}{l}\text { Customer's sustainable value through transparency about production and consumption } \\
\text { systems. Ecological and social value through customer value/measurable ecological and/or } \\
\text { social value in concert with economic value. }\end{array}$ \\
\hline Krantz (2010) & & Better value; customer's sustainable value through transparency about co-benefits \\
\hline $\begin{array}{l}\text { Lüdeke-Freund } \\
\text { (2010) }\end{array}$ & & $\begin{array}{l}\text { Superior/extended customer value, company and society \& environment/public customer } \\
\text { value/public value propositions }\end{array}$ \\
\hline Patala et al. (2016) & & $\begin{array}{l}\text { Customer's sustainable value through co-benefits such as health, design, energy savings. } \\
\text { Sustainable value proposition: economic, environmental, social }\end{array}$ \\
\hline $\begin{array}{l}\text { Schaltegger et al. } \\
\text { (2016) }\end{array}$ & & $\begin{array}{l}\text { Sustainable customer value through value for broad stakeholder network including natural } \\
\text { environment }\end{array}$ \\
\hline $\begin{array}{l}\text { Zott and Amit } \\
\qquad(2010)\end{array}$ & Customer value & \\
\hline $\begin{array}{l}\text { Value creation \& } \\
\text { delivery }\end{array}$ & Business, value chain, relevant value network partners & $\begin{array}{l}\text { Business and interlinked value chains plus stakeholder network including new and possibly } \\
\text { unusual partners }\end{array}$ \\
\hline $\begin{array}{l}\text { Bocken et al. } \\
\text { (2013) }\end{array}$ & & Wider set of stakeholders \\
\hline $\begin{array}{l}\text { Boons and Lüdeke- } \\
\text { Freund (2013) }\end{array}$ & & Sustainable supply chain management and responsibility for stakeholders \\
\hline Chen et al. (2017) & & Internal, value chain and competitor/other organizations \\
\hline $\begin{array}{l}\text { Chesbrough and } \\
\text { Schwartz (2007) }\end{array}$ & $\begin{array}{l}\text { Value chain and value network of suppliers, customers } \\
\text { and rivals }\end{array}$ & \\
\hline $\begin{array}{l}\text { Evans, } \\
\text { Vladimirova, } \\
\text { et al. (2017) }\end{array}$ & Business and value chain & $\begin{array}{l}\text { Business and value chain plus stakeholder network including new and possibly unusual } \\
\text { partners }\end{array}$ \\
\hline Freeman (1984) & & Value network instead of value chain \\
\hline Krantz (2010) & & Interlinked value chains \\
\hline
\end{tabular}


(continued)

\begin{tabular}{|c|c|c|}
\hline & Business Model & Sustainable business model \\
\hline Value form & Value created and captured & $\begin{array}{l}\text { Value created and captured plus value absence, destroyed, missed or surplus, new value } \\
\text { opportunities }\end{array}$ \\
\hline $\begin{array}{l}\text { Lüdeke-Freund } \\
\text { (2010) }\end{array}$ & & Network of partners \\
\hline Richardson (2008) & $\begin{array}{l}\text { Value chain, activity system, business processes, value } \\
\text { network of suppliers, partners and customers }\end{array}$ & \\
\hline $\begin{array}{l}\text { Stubbs and Cocklin } \\
\text { (2008) }\end{array}$ & & $\begin{array}{l}\text { Stakeholders in the network; for example, non-government organizations (NGOs), the media, } \\
\text { upstream and downstream supply chain players, financial markets, and investors. }\end{array}$ \\
\hline $\begin{array}{l}\text { Zott and Amit } \\
\text { (2010) }\end{array}$ & & Firm in concert with its partners \\
\hline Value capture & Economic business value (monetary \& non-monetary) & Societal, environmental and economic value \\
\hline $\begin{array}{l}\text { Boons and Lüdeke- } \\
\text { Freund (2013) }\end{array}$ & & $\begin{array}{l}\text { Appropriate distribution of economic costs and benefits, and ecological and social value } \\
\text { capture }\end{array}$ \\
\hline Chesbrough (2010) & Firm revenue & \\
\hline $\begin{array}{l}\text { Dyllick and } \\
\text { Hockerts (2002) }\end{array}$ & & Natural, societal and business \\
\hline $\begin{array}{l}\text { Evans, } \\
\text { Vladimirova, } \\
\text { et al. (2017a,b) }\end{array}$ & Economic value & Societal, environmental and economic value \\
\hline Madden (2017) & & $\begin{array}{l}\text { Environment, local communities, other 'public interest' representatives next to customers and } \\
\text { employees }\end{array}$ \\
\hline Richardson (2008) & Revenue and business economics & \\
\hline $\begin{array}{l}\text { Schaltegger et al. } \\
\text { (2016) }\end{array}$ & & Economic value capture through societal and environmental value capture \\
\hline $\begin{array}{l}\text { Stubbs and Cocklin } \\
\text { (2008) }\end{array}$ & & Financial, Environmental, Social outcomes \\
\hline Teece (2010) & Business value (monetary \& non-monetary) & \\
\hline $\begin{array}{l}\text { Zott and Amit } \\
\quad(2010)\end{array}$ & Business profit through revenue model & \\
\hline
\end{tabular}

\section{Appendix B. Main collaboration partners, partner novelty and targeted value creation}

\begin{tabular}{|c|c|c|c|c|c|c|}
\hline Case & $\begin{array}{l}\text { Main } \\
\text { Collaboration } \\
\text { Partners }\end{array}$ & $\begin{array}{l}\text { Partner } \\
\text { Novelty }\end{array}$ & Societal Value Propositions & $\begin{array}{l}\text { Environmental Value } \\
\text { Propositions }\end{array}$ & $\begin{array}{l}\text { Partner Value } \\
\text { Propositions }\end{array}$ & $\begin{array}{l}\text { Consumer Value } \\
\text { Propositions }\end{array}$ \\
\hline $\begin{array}{l}\text { One (initiator: } \\
\text { Heijmans) }\end{array}$ & $\begin{array}{l}\text { Public housing } \\
\text { agency } \\
\text { Private } \\
\text { investment } \\
\text { fund } \\
\text { Municipalities } \\
\text { Local citizens } \\
\text { Private energy/ } \\
\text { utilities } \\
\text { company } \\
\text { Leasing } \\
\text { Corporations } \\
\text { Producer }\end{array}$ & $\begin{array}{l}\text { Familiar } \\
\text { Familiar } \\
\text { Familiar } \\
\text { New } \\
\text { Familiar } \\
\text { New } \\
\text { New }\end{array}$ & $\begin{array}{l}\text { - Affordable high-quality housing for } \\
\text { young, single professionals } \\
\text { - Positive contribution to empty } \\
\text { areas by attracting new cash } \\
\text { flows, community binding, } \\
\text { improving safety Emerged } \\
\text { - Housing for asylum seekers (new } \\
\text { market) }\end{array}$ & $\begin{array}{l}\text { - Resource recovery through } \\
\text { circularity } \\
\text { - High energy efficiency } \\
\text { - All-electric }\end{array}$ & $\begin{array}{l}\text { Intermediaries } \\
\text { (investors, housing } \\
\text { corporations, leasing } \\
\text { companies): } \\
\text { - Innovative product } \\
\text { with a good return } \\
\text { - Moveable housing } \\
\text { - Long-term } \\
\text { investment } \\
\text { Housing corporations } \\
\text { - Temporary housing } \\
\text { Municipalities } \\
\text { - Temporary design } \\
\text { housing to } \\
\text { improve urban } \\
\text { quality }\end{array}$ & $\begin{array}{l}\text { Immediate: } \\
\text { - Flexible, independent, } \\
\text { qualitative and affordable } \\
\text { rental housing } \\
\text { Long-term: } \\
\text { - (Dutch) Design } \\
\text { - Socially } \\
\text { environmentally and } \\
\text { sustainable municipalities } \\
\end{array}$ \\
\hline $\begin{array}{l}\text { Niaga (initiator: } \\
\text { DSM-Niaga) }\end{array}$ & $\begin{array}{l}\text { MNE } \\
\text { (chemical/ } \\
\text { material } \\
\text { producer) } \\
\text { Carpet } \\
\text { producer }\end{array}$ & $\begin{array}{l}\text { New } \\
\text { New }\end{array}$ & $\begin{array}{l}\text { - Improve population health } \\
\text { through less allergy and asthma } \\
\text { - Radically decrease polyester } \\
\text { pollution }\end{array}$ & $\begin{array}{l}\text { - Full resource recovery } \\
\text { - Elimination of raw resource } \\
\text { extraction } \\
\text { - Elimination of waste } \\
\text { - } 90 \% \text { less energy usage during } \\
\text { production and recycling }\end{array}$ & $\begin{array}{l}\text { Manufacturer } \\
\text { - Proud to produce } \\
\text { Niaga market } \\
\text { - New sa savings } \\
\text { opportunity } \\
\text { through (limited) } \\
\text { exclusivity } \\
\text { - Future } \\
\text { sustainability } \\
\text { Retailer Cost through easy } \\
\text { - } \\
\text { application and } \\
\text { replacement }\end{array}$ & $\begin{array}{l}\text { Immediate: } \\
\text { - Buy an experience } \\
\text { - No smoke in case of fire } \\
\text { - Lightweight \& no smell } \\
\text { - Easy use; replaceable } \\
\text { - Return value } \\
\text { Long-term: } \\
\text { - Improved health } \\
\text { - Pure material } \\
\text { - No waste }\end{array}$ \\
\hline
\end{tabular}




\begin{tabular}{|c|c|c|c|c|c|c|}
\hline Case & $\begin{array}{l}\text { Main } \\
\text { Collaboration } \\
\text { Partners }\end{array}$ & $\begin{array}{l}\text { Partner } \\
\text { Novelty }\end{array}$ & Societal Value Propositions & $\begin{array}{l}\text { Environmental Value } \\
\text { Propositions }\end{array}$ & $\begin{array}{l}\text { Partner Value } \\
\text { Propositions }\end{array}$ & $\begin{array}{l}\text { Consumer Value } \\
\text { Propositions }\end{array}$ \\
\hline $\begin{array}{l}\text { Futureproof } \\
\text { (initiator: } \\
\text { Kingspan) }\end{array}$ & $\begin{array}{l}\text { Farmer } \\
\text { Energy } \\
\text { cooperation } \\
\text { (Regional) } \\
\text { banks } \\
\text { Regional } \\
\text { builders } \\
\text { Asbestos } \\
\text { removers } \\
\text { Solar installers }\end{array}$ & $\begin{array}{l}\text { Familiar } \\
\text { New } \\
\text { New } \\
\text { Familiar } \\
\text { New } \\
\text { Familiar }\end{array}$ & $\begin{array}{l}\text { - Discard hazardous substances to } \\
\text { improve health }\end{array}$ & $\begin{array}{l}\text { - Renewable energy (solar } \\
\text { panels) } \\
\text { - Energy efficiency (intelligent } \\
\text { lighting and isolation) }\end{array}$ & $\begin{array}{l}\text { - Decreased risk } \\
\text { asbestos } \\
\text { Banks } \\
\text { - Investment } \\
\text { opportunity/cash } \\
\text { flow } \\
\text { - Risk sharing, } \\
\text { decreased risk of } \\
\text { having loan on } \\
\text { asbestos } \\
\text { Energy company } \\
\text { - Long-term cash } \\
\text { flow } \\
\text { - Risk sharing }\end{array}$ & $\begin{array}{l}\text { - Safe asbestos removal } \\
\text { without moving supplies } \\
\text { and animals } \\
\text { - Cost-neutral: monthly fee } \\
\text { based on solar revenue } \\
\text { - Less administration; } \\
\text { better maintenance, } \\
\text { warranty \& insurance } \\
\text { - Overcome investment } \\
\text { barrier } \\
\text { Long-term: } \\
\text { - Incentive for sustainable } \\
\text { certification } \\
\text { - Increased fire safety } \\
\text { - Increased business } \\
\text { premises; property and } \\
\text { sales value, access to } \\
\text { finance and insurance }\end{array}$ \\
\hline $\begin{array}{l}\text { Ecor Circular } \\
\text { Friesland } \\
\text { (initiator: } \\
\text { Noble } \\
\text { Environmental) } \\
\end{array}$ & $\begin{array}{l}\text { Public regional } \\
\text { Investment \& } \\
\text { Development } \\
\text { Circular } \\
\text { Friesland } \\
\text { (public) } \\
\text { Local industry } \\
\text { Private waste } \\
\text { collector and } \\
\text { processor }\end{array}$ & $\begin{array}{l}\text { New } \\
\text { New } \\
\text { New } \\
\text { New }\end{array}$ & $\begin{array}{l}\text { - Regional cohesion through } \\
\text { circularity } \\
\text { - Regional job creation } \\
\text { - Elimination of harmful VOCs }\end{array}$ & $\begin{array}{l}\text { - Elimination of cellulose waste, } \\
\text { harmful VOCs \& waste in } \\
\text { production } \\
\text { - Reduced transport } \\
\text { - } 100 \% \text { certified bio-based } \\
\text { - } 100 \% \text { resource recovery } \\
\text { (urban, farm and forest waste } \\
\text { materials), reducing } \\
\text { incineration and landfill } \\
\text { - Alternative for traditional } \\
\text { wood, plywood, corrugated } \\
\text { and plastics } \\
\text { - } 99 \% \text { water reuse in production } \\
\text { - Zero impact factories } \\
\end{array}$ & $\begin{array}{l}\text { Provinces/ } \\
\text { municipalities/ } \\
\text { regional public } \\
\text { investors: } \\
\text { - Circular region, } \\
\text { sustainability } \\
\text { performance } \\
\text { - Job creation } \\
\text { - Regional cohesion } \\
\text { Private investors } \\
\text { - Good investment } \\
\text { - Global elimination } \\
\text { MDFs } \\
\text { - Fair material use } \\
\text { Sourcing \& } \\
\text { application potentials } \\
\text { - Sales } \\
\text { - Part of circular } \\
\text { movement } \\
\text { - Sustainability } \\
\text { performance }\end{array}$ & $\begin{array}{l}\text { Immediate: } \\
\text { - Avoiding waste costs } \\
\text { - Advanced design and } \\
\text { performance } \\
\text { - } 100 \% \text { non-toxic and } \\
\text { recycled } \\
\text { - Contribution to LEED } \\
\text { credits } \\
\text { Long-term: } \\
\text { - Community creation: } \\
\text { designers, craftsmen } \\
\end{array}$ \\
\hline $\begin{array}{l}\text { Food-for-Feed- } \\
\text { for-Food } \\
\text { (initiator: } \\
\text { Nijsen-Granico) }\end{array}$ & $\begin{array}{l}\text { Municipality } \\
\text { Environmental } \\
\text { NGO }\end{array}$ & $\begin{array}{l}\text { New } \\
\text { Familiar }\end{array}$ & $\begin{array}{l}\text { - Increased public space } \\
\text { - Increased food availability, } \\
\text { elimination of human-animal } \\
\text { competition for land } \\
\text { - Contribute to solving manure } \\
\text { problem } \\
\text { - Decrease smell and improve air } \\
\text { quality in areas surrounding } \\
\text { stables }\end{array}$ & $\begin{array}{l}\text { - No additional need for } \\
\text { resources \& agricultural land } \\
\text { (forests, soy, wheat) } \\
\text { - Radical carbon emission } \\
\text { reduction through local } \\
\text { sourcing \& production process } \\
\text { - Less phosphate pig manure }\end{array}$ & $\begin{array}{l}\text { Pig farmers } \\
\text { - Decrease manure } \\
\text { problem } \\
\text { - Price/volume } \\
\text { certainty } \\
\text { - Improved image } \\
\text { Retailer } \\
\text { - Circularity } \\
\text { - Avoid waste costs } \\
\text { - Improved image \& } \\
\text { avoid NGO } \\
\text { campaigns } \\
\text { Butchers } \\
\text { - No value identified } \\
\text { NGO } \\
\text { - No additional } \\
\text { resource need \& } \\
\text { agricultural land } \\
\text { - Reduced CO2 } \\
\text { emission through } \\
\text { regional sourcing \& } \\
\text { production } \\
\text { - Less phosphate pig } \\
\text { manure }\end{array}$ & $\begin{array}{l}\text { Immediate: } \\
\text { - Certified meat } \\
\text { - Improved taste and } \\
\text { structure } \\
\text { - Improved animal welfare } \\
\text { - Improved environmental } \\
\text { performance } \\
\text { Long-term: } \\
\text { - Improved environmental } \\
\text { performance } \\
\end{array}$ \\
\hline $\begin{array}{l}\text { Kipster (initiator: } \\
\text { Kipster) }\end{array}$ & $\begin{array}{l}\text { Boundary } \\
\text { workers } \\
\text { Retailer } \\
\text { NGO } \\
\text { Builders } \\
\text { Food suppliers }\end{array}$ & $\begin{array}{l}\text { New } \\
\text { Familiar } \\
\text { Familiar } \\
\text { Familiar } \\
\text { New }\end{array}$ & $\begin{array}{l}\text { - Chicken food from waste streams } \\
\text { does not impede with food for } \\
\text { human consumption } \\
\text { - Esthetic and functional design } \\
\text { - Transparency: visitor and } \\
\text { education center } \\
\text { - Suitable for urban agriculture } \\
\text { - Sell rooster meat to help meeting } \\
\text { food demands }\end{array}$ & $\begin{array}{l}\text { - Radically lowering ammonia } \\
\text { \& particulate matter } \\
\text { - Chicken food from waste } \\
\text { streams } \\
\text { - Energy-positive through solar } \\
\text { panels } \\
\text { - No fossil fuel use } \\
\text { - Local packaging and direct } \\
\text { distribution limits transport }\end{array}$ & $\begin{array}{l}\text { Retailer } \\
\text { - Three-star certified } \\
\text { egg from Animal } \\
\text { Protection } \\
\text { - Environmental } \\
\text { certification } \\
\text { - Energy-neutral } \\
\text { - Exclusivity } \\
\text { Farmer }\end{array}$ & $\begin{array}{l}\text { Immediate: } \\
\text { - 'The best farm with the } \\
\text { best egg for the best price' } \\
\text { - Human, animal, and } \\
\text { environmentally friendly } \\
\text { egg }\end{array}$ \\
\hline
\end{tabular}




\begin{tabular}{|c|c|c|c|c|c|c|}
\hline Case & $\begin{array}{l}\text { Main } \\
\text { Collaboration } \\
\text { Partners }\end{array}$ & $\begin{array}{l}\text { Partner } \\
\text { Novelty }\end{array}$ & Societal Value Propositions & $\begin{array}{l}\text { Environmental Value } \\
\text { Propositions }\end{array}$ & $\begin{array}{l}\text { Partner Value } \\
\text { Propositions }\end{array}$ & $\begin{array}{l}\text { Consumer Value } \\
\text { Propositions }\end{array}$ \\
\hline $\begin{array}{l}\text { New Karolinska } \\
\text { partnership } \\
\text { (initiator: } \\
\text { Philips } \\
\text { Healthcare) }\end{array}$ & $\begin{array}{l}\text { County Council } \\
\text { (initiator) } \\
\text { Competitor } 1 \\
\text { (private } \\
\text { healthcare) } \\
\text { Competitor } 2 \\
\text { (private } \\
\text { healthcare) } \\
\text { Hospital (semi- } \\
\text { public) } \\
\text { Users } \\
\text { Private } \\
\text { construction } \\
\text { company }\end{array}$ & $\begin{array}{l}\text { Familiar } \\
\text { New } \\
\text { New } \\
\text { Familiar } \\
\text { Familiar } \\
\text { New }\end{array}$ & $\begin{array}{l}\text { - Increase affordable healthcare } \\
\text { - Increase access to healthcare }\end{array}$ & $\begin{array}{l}\text { - Sell rooster meat instead } \\
\text { producing extra chicken } \\
\text { - Energy efficiency, material } \\
\text { and chemical declarations, } \\
\text { waste disposals } \\
\text { - Less need for raw materials } \\
\text { through circularity }\end{array}$ & $\begin{array}{l}\text { - Fair pricing } \\
\text { NGOs } \\
\text { - Contribution to } \\
\text { sustainable egg } \\
\text { production } \\
\text { Hospital } \\
\text { - Uptime warranty } \\
\text { - Freedom of product } \\
\text { choice (also } \\
\text { competitor's) } \\
\text { - Fixed price } \\
\text { - Access to latest } \\
\text { technology } \\
\text { - Unburdening } \\
\text { responsibility } \\
\text { equipment }\end{array}$ & $\begin{array}{l}\text { Immediate: } \\
\text { - More affordable, } \\
\text { convenient and high } \\
\text { quality healthcare }\end{array}$ \\
\hline $\begin{array}{l}\text { BeeBanking } \\
\text { (initiator: } \\
\text { Stroom The } \\
\text { Hague) }\end{array}$ & $\begin{array}{l}\text { Artist } \\
\text { Beekeepers } \\
\text { (association) } \\
\text { Crowd } \\
\text { Retailer } \\
\text { Private } \\
\text { investors } \\
\text { NGOs } \\
\text { Sustainability } \\
\text { fund } \\
\text { Politicians }\end{array}$ & $\begin{array}{l}\text { New } \\
\text { New } \\
\text { New } \\
\text { New } \\
\text { New } \\
\text { Familiar } \\
\text { Familiar } \\
\text { New }\end{array}$ & $\begin{array}{l}\text { - Increased awareness of food } \\
\text { production and bee mortality }\end{array}$ & $\begin{array}{l}\text { - Increased awareness of food } \\
\text { production and bee mortality }\end{array}$ & $\begin{array}{l}\text { Artist } \\
\text { - Project sale } \\
\text { Beekeepers } \\
\text { - Promotion for craft } \\
\text { - Contribute to } \\
\text { environmental goal } \\
\text { Private investors/ } \\
\text { citizens } \\
\text { - Contribute to life } \\
\text { - Honey package as } \\
\text { return for financial } \\
\text { support } \\
\text { Retail } \\
\text { - Honey sales }\end{array}$ & $\begin{array}{l}\text { Immediate: } \\
\text { - Contribute to life } \\
\text { - Honey package } \\
\text { - Co-benefit } \\
\text { - Taste of urban honey } \\
\end{array}$ \\
\hline $\begin{array}{l}\text { Urgenda } \\
\text { (initiator: } \\
\text { Thuisbaas) }\end{array}$ & $\begin{array}{l}\text { House owners } \\
\text { (association) } \\
\text { Solar installers } \\
\text { Heath pump } \\
\text { installers } \\
\text { Infrared } \\
\text { installers } \\
\text { Municipality }\end{array}$ & $\begin{array}{l}\text { Familiar } \\
\text { New } \\
\text { New } \\
\text { New } \\
\text { New }\end{array}$ & $\begin{array}{l}\text { - Contribution to mitigate climate } \\
\text { change through energy-neutral } \\
\text { home }\end{array}$ & $\begin{array}{l}\text { - Contribution to mitigate } \\
\text { climate change through } \\
\text { energy-neutral home }\end{array}$ & $\begin{array}{l}\text { Suppliers \& } \\
\text { consultants } \\
\text { - Market entrance } \\
\text { opportunity } \\
\text { - Opportunity for } \\
\text { scale-up }\end{array}$ & $\begin{array}{l}\text { Immediate: } \\
\text { - Zero-on-the-meter } \\
\text { warranty } \\
\text { - Cost-friendly investment } \\
\text { with co-funding } \\
\text { municipality } \\
\text { - Customized } 8 \text { step plan } \\
\text { - Eliminate CO2 emissions } \\
\text { - Self-sufficiency } \\
\text { - Financial assistance: } \\
\text { subsidies, loans, savings } \\
\text { - Long-term: Increased house value } \\
\text { - House sold faster }\end{array}$ \\
\hline
\end{tabular}

\section{References}

Abbott, A., 1995. Things Of Boundaries. Soc. Res 62 (4), 857-882. http://www.jstor. org/stable/40971127.

Achterberg, E., Hinfelaar, J., Bocken, N., 2016. Master circular business with the value hill. Retrieved from. https://www.circle-economy.com/wp-content/uploads 2016/09/finance-white-paper-20160923.pdf.

Al-Debei, M.M., Avison, D., 2010. Developing a unified framework of the business model concept. Eur. J. Inf. Syst. 19 (3), 359-376. https://doi.org/10.1057/ ejis.2010.21.

Ashraf, N., Ahmadsimab, A., Pinkse, J., 2017. From animosity to affinity: the interplay of competing logics and interdependence in cross-sector partnerships. J. Manag. Stud. 54, 793-822.

Austin, J., Seitanidi, M., 2012a. Collaborative value creation: a review of partnering between nonprofits and businesses. Part 2: partnership processes and outcomes. Nonprofit Voluntary Sect. Q. 41 (6), 929-968.

Austin, J., Seitanidi, M., 2012b. Collaborative value creation: a review of partnering between nonprofits and businesses: Part 1. Value creation spectrum and collaboration stages. Nonprofit Voluntary Sect. Q. 41 (5), 726-758.

Baldassarre, B., Calabretta, G., Bocken, N., Jaskiewicz, T., 2017. Bridging sustainable business model innovation and user-driven innovation: a process for sustainable value proposition design. J. Clean. Prod. 147 https://doi.org/10.1016 j.jclepro.2017.01.081.

Ballon, P., 2007. Business modelling revisited: the configuration of control and value. J. Pol. Reg. Strat. Telec. Inf. Med. 9 (5), 6-19.

Barney, J., Wright, M., Ketchen, D.J., 2001. The resource-based view of the firm: ten years after 1991. J. Manag. 27, 625-641. https://doi.org/10.1177/ 014920630102700601.

Berger, I.E., Cunningham, P.H., Drumwright, M.E., 2004. Social alliances: company/ nonprofit collaboration. Calif. Manag. Rev. 47 (1), 58-90. https://doi.org/ $10.2307 / 41166287$.

Berglund, H., Sandström, C., 2013. Business model innovation from an open systems perspective: structural challenges and managerial solutions. Int. J. Prod. Dev. 18 (3-4), 274-285.

Bitzer, V., Hamann, R., 2015. The Business of Social and Environmental Innovation. The Business of Social and Environmental Innovation. Springer, Cham.

Bleicher, K., 1994. Integrative management in a time of transformation. Long. Range Plan. 27 (5), 136-144.

Bocken, N., Allwood, J., 2012. Strategies to Reduce the Carbon Footprint of Consumer Goods by Influencing Stakeholders. J. Clean. Prod. 35, 118-129. https://doi.org/ 10.1016/j.jclepro.2012.05.031.

Bocken, N., Boons, F., Baldassarre, B., 2019. Sustainable business model experimentation by understanding ecologies of business models. J. Clean. Prod. 208, 1498-1512.

Bocken, N., Rana, P., Short, S.W., 2015. Value mapping for sustainable business thinking. J. Ind. Prod. Eng. 32 (1), 67-81. https://doi.org/10.1080/ 21681015.2014.1000399.

Bocken, N., Schuit, C., Kraaijenhagen, C., 2018. Experimenting with a circular business model: lessons from eight cases. Environ. Innov. Soc. Transit. https:// doi.org/10.1016/j.eist.2018.02.001 (in press).

Bocken, N., Short, S.W., Rana, P., Evans, S., 2013. A value mapping tool for sustainable business modelling. Corp. Govern. 13 (5), 482-497. https://doi.org/10.1108/CG- 
06-2013-0078.

Bocken, N., Short, S.W., Rana, P., Evans, S., 2014. A literature and practice review to develop sustainable business model archetypes. J. Clean. Prod. 65, 42-56. https://doi.org/10.1016/j.jclepro.2013.11.039.

Bocken, N., Weissbrod, I., Tennant, M., 2016. Business model experimentation for sustainability. In: Paper Presented at the Sustainable Design \& Manufacturing Conference (Crete).

Bolton, D., Landells, T., 2015. Reconceptualizing power relations as sustainable business practice. Bus. Strateg. Environ. 24, 604-616.

Boons, F., Chertow, M., Park, J., Spekkink, W., Shi, H., 2016. Industrial symbiosis dynamics and the problem of equivalence: proposal for a comparative framework. J. Ind. Ecol. 21 (4), 938-952. https://doi.org/10.1111/jiec.12468.

Boons, F., Lüdeke-Freund, F., 2013. Business models for sustainable innovation: state of the art and steps towards a research agenda. J. Clean. Prod. 45, 9-19. https:// doi.org/10.1016/j.jclepro.2012.07.007.

Bouwman, H., Faber, E., Haaker, T., Kijl, B., De Reuver, M., 2008. Conceptualizing the STOF model. In: Bouwman, H., De Vos, H., Haaker, T. (Eds.), Mobile Service Innovation and Business Models. Springer Berlin Heidelberg, Berlin, Heidelberg, pp. 31-70.

08 Breckenridge, J., 2009. Demistifying theoretical sampling in grounded theory research. Grounded Theor. Rev. (2) Retrieved from http:// groundedtheoryreview.com/2009/06/30/847/.

Brehmer, M., Podoynitsyna, K., Langerak, F., 2018. Sustainable business models as boundary-spanning systems of value transfers. J. Clean. Prod. 172, 4514-4531. https://doi.org/10.1016/j.jclepro.2017.11.083.

Breuer, H., Lüdeke-Freund, F., 2017. Values-based network and business model innovation. Int. J. Innov. Manag. 21, 1750028. https://oi.org/10.1142/ s1363919617500281, 03

Brown, H., Vergragt, P., 2008. Bounded socio-technical experiments as agents of systemic change: the case of a zero-energy residential building. Technol. Forecast. Soc. 75 (1), 107-130. https://doi.org/10.1016/j.techfore.2006.05.014.

Carlile, P.R., 2002. A pragmatic view of knowledge and boundaries: boundary objects in new product development. Organ. Sci. 13 (4), 442-455. https://doi.org/ 10.1287 /orsc.13.4.442.2953.

Charmaz, K., 2014. Constructing Grounded Theory, second ed. ed. Sage Publications, London.

Chen, L., Zhao, X., Tang, O., Price, L., Zhang, S., Zhu, W., 2017. Supply chain collaboration for sustainability: a literature review and future research agenda. Int. J. Prod. Econ. https://doi.org/10.1016/j.ijpe.2017.04.005.

Chesbrough, H., 2010. Business model innovation: opportunities and barriers. Long. Range Plan. 43 (2), 354-363.

Chesbrough, H., Schwartz, K., 2007. Innovating business models with Codevelopment partnerships. Res. Technol. Manag. 50 (1), 55-59. https:// doi.org/10.1080/08956308.2007.11657419.

Covey, S.M.R., 2006. The Speed of Trust: the One Thing that Changes Everything. Free Press, New York, N.Y

Crosby, B.C., Bryson, J.M., 2010. Integrative leadership and the creation and maintenance of CrossSector collaborations. Leadersh. O. 21 (2), 211-230.

Dentchev, N., Rauter, R., Jóhannsdóttir, L., Snihur, Y., Rosano, M., Baumgartner, R., et al., 2018. Embracing the variety of sustainable business models: a prolific field of research and a future research agenda. J. Clean. Prod. 194, 695-703.

Di Domenico, M., Tracey, P., Haugh, H., 2009. The dialectic of social exchange: theorizing corporate-social enterprise collaboration. Organ. Stud. 30 (8), 887-907. https://doi.org/10.1177/017084060933495.

Diepenmaat, H., 2018. The Path of Humanity: Societal Innovation for the World of Tomorrow. Parthenon, Almere.

Dyer, H., Sing, H., 1998. The relational view: cooperative strategy and sources of interorganizational competititive advantage. Acad. Manag. Rev. 23 (4), 660-679. http://www.jstor.org/stable/259056.

Dyllick, T., Hockerts, K., 2002. Beyond the business case for corporate sustainability. Bus. Strateg. Environ. 11 (2), 130-141. https://doi.org/10.1002/bse.323.

Dyllick, T., Muff, K., 2016. Clarifying the meaning of sustainable business. Organ. Environ. 29 (2), 156-174. https://doi.org/10.1177/1086026615575176.

Eisenhardt, K.M., 1989. Building theories from case study research. Acad. Manag. Rev. 14 (4), 532-550. https://doi.org/10.2307/258557.

Eisenhardt, K.M., Martin, J.A., 2000. Dynamic capabilities: what are they? Strateg. Manag. J. 21, 1105-1121. https://doi.org/10.1002/1097-0266(200010/11)21:10/ 11.

Evans, S., Fernando, L., Yang, M., 2017a. Sustainable Value Creation - from Concept towards Implementation Sustain. Man., pp. 203-220.

Evans, S., Vladimirova, D., Holgado, M., Yang, M., 2017b. Business model innovation for sustainability: towards a unified perspective for creation of sustainable business models. Bus. Strateg. Environ. https://doi.org/10.1002/bse.1939.

Fischer, A., Pascucci, S., 2017. Institutional incentives in circular economy transition: the case of material use in the Dutch textile industry. J. Clean. Prod. 155 (2), 17-32. https://doi.org/10.1016/j.jclepro.2016.12.038.

Fleming, L., Waguespack, D.M., 2007. Brokerage, boundary spanning, and leadership in open innovation communities. Organ. Sci. 18 (2), 165-180. https://doi.org/ 10.1287 /orsc. 1060.0242

Foss, N.J., Saebi, T., 2017. Fifteen years of research on business model innovation: how far have we come, and where should we go? J. Manag. 43 (1), 200-227.

Freeman, R., 1984. Strategic Management: a Stakeholder Approach. Pitman Publishing, Boston.

Freudenreich, B., Lüdeke-Freund, F., Schaltegger, S., 2019. A stakeholder theory perspective on business models: value creation for sustainability. J. Bus. Ethics
1-16. https://doi.org/10.1007/s10551-019-04112-z.

Garcia-Castro, R., Aguilera, R.V., 2015. Incremental value creation and appropriation in a world with multiple stakeholders. Strateg. Manag. J. 36 (1), 137-147. https://doi.org/10.1002/smj.2241.

Geissdoerfer, M., Savaget, P., Bocken, N., Hultink, E.J., 2017. The circular economy -A new sustainability paradigm? J. Clean. Prod. 143, 757-768. https://doi.org/ 10.1016/j.jclepro.2016.12.048.

Geissdoerfer, M., Vladimirova, D., Evans, S., 2018. Sustainable business model innovation: a review. J. Clean. Prod. 198, 401-416.

Gieryn, T.F., 1983. Boundary-work and the demarcation of science from nonscience: strains and interests in professional ideologies of scientists. Am. Sociol. Rev. 48 (6), 781-795. https://doi.org/10.2307/2095325.

Glaser, B.G., 1978. Theoretical Sensitivity: Advances in the Methodology of Grounded Theory. Sociology Press, Mill Valley, CA.

Googins, B., Rochlin, S.A., 2002. Creating the partnership society: understanding the rhetoric and reality of cross-sectoral partnerships. Bus. Soc. Rev. 105, 127-144. https://doi.org/10.1111/0045-3609.00068.

Haaker, T., Bouwman, H., Janssen, W., de Reuver, M., 2017. Business model stress testing: a practical approach to test the robustness of a business model. Futures 89, 14-25. https://doi.org/10.1016/j.futures.2017.04.003.

Halffman, W., 2003. Boundaries of Regulatory Science: Eco/toxicology and Aquatic Hazards of Chemicals in the US, England and the Netherlands Sci. Dynam. University of Amsterdam, Amsterdam, pp. 439-477.

Harrington, T.S., Srai, J.S., 2016. Designing a 'concept of operations' architecture for next-generation multi-organisational service networks. AI Soc. https://doi.org 10.1007/s00146-016-0664-5.

Hellström, M., Tsvetkova, A., Gustafsson, M., Wikström, K., 2015. Collaboration mechanisms for business models in distributed energy ecosystems. J. Clean. Prod. 102 https://doi.org/10.1016/j.jclepro.2015.04.128.

Heracleous, L., 2004. Boundaries in the study of organization. Hum. Relat. 57 (1) 95-103. https://doi.org/10.1177/0018726704042716.

Hoppe, R., 2010. From 'Knowledge Use' towards 'Boundary Work'. Sketch of an Emerging New Agenda for Inquiry into Science-Policy Interaction Knowledge Democracy. Consequences for Science, Politics and Media, Heidelberg.

Joyce, A., Paquin, R.L., 2016. The triple layered business model canvas: a tool to design more sustainable business models. J. Clean. Prod. 135, 1474-1486.

Huxham, C., Vangen, S., 2000. Ambiguity, Complexity and Dynamics in the Membership of Collaboration. Hum. Relat. 53 (6), 771-806. https://doi.org/10.1177 0018726700536002.

Jay, J., 2017. Navigating paradox as a mechanism of change and innovation in hybrid organizations. Acad. Manag. J. 56, 137-159.

Koschmann, M., Kuhn, T., Pfarrer, M., 2012. A communicative framework of value in cross-sector partnerships. Acad. Manag. Rev. 37, 332-354. https://doi.org/ 10.5465/amr.2010.0314.

Kraaijenhagen, C., Van Oppen, C., Bocken, N., 2016. Circular Business. Collaborate \& Circulate., Amersfoort, The Netherlands (Circular Collaboration).

Krantz, R., 2010. A new vision of sustainable consumption: the business challenge. J. Ind. Ecol. 14 (1) https://doi.org/10.1111/j.1530-9290.2009.00220.x.

Lamont, M., Molnar, V., 2002. The study of boundaries in the social sciences. Annu. Rev. Sociol. 28, 167-195. https://doi.org/10.1146/annurev.soc.28.110601.141107.

Le Ber, M., Branzei, O., 2010a. Towards a critical theory of value creation in crosssector partnerships. Organization 17 (599), 599-629. https://doi.org/10.1177/ 1350508410372621

Le Ber, M., Branzei, O., 2010b. Value frame fusion in cross sector interactions. J. Bus. Ethics 94 (1), 163-195. https://doi.org/10.1007/s10551-011-0785-1.

Leising, E., Quist, J., Bocken, N., 2018. Circular economy in the building sector: three cases and a collaboration tool. J. Clean. Prod. https://doi.org/10.1016 j.jclepro.2017.12.010.

Lüdeke-Freund, F., 2010. Towards a conceptual framework of business models for sustainability. In: Paper Presented at the Knowledge Collaboration \& Learning for Sustainable Innovation [Conference]. Delft. http://ssin.com/ abstract $=2189922$

Lüdeke-Freund, F., Dembek, K., 2017. Sustainable Business Model Research and Practice: Emerging Field or Passing Fancy? J. Clean. Prod. 168, 1668-1678. https://doi.org/10.1016/j.jclepro.2017.08.093.

Madden, B.J., 2017. The purpose of the firm, valuation, and the management of intangibles. J. Appl. Corp. Finance 29 (2), 76-86. https://doi.org/10.1111/ jacf.12235.

Matos, S., Silvestre, B., 2013. Managing stakeholder relations when developing sustainable business models: the case of the Brazilian energy sector. J. Clean. Prod. 45, 61-73. https://doi.org/10.1016/j.jclepro.2012.04.023.

Ojasalo, J., 2008. Management of innovation networks: a case study of different approaches. Eur. J. Innov.Manage. 11 (1), 51-86. https://doi.org/10.1108/ 14601060810845222

O’Mahony, S., Bechky, B.A., 2008. Boundary organizations: enabling collaboration among unexpected allies. Adm Sci. 0 53 (3), 422-459.

Oskam, I., Bossink, B., de Man, A.P., 2018. The interaction between network ties and business modeling: case studies of sustainability-oriented innovations. J. Clean. Prod. 177, 555-566. https://doi.org/10.1016/j.jclepro.2017.12.202.

Osterwalder, A., Pigneur, Y., 2010. Business Model Generation: A Handbook for Visionaries, Game Changers and Challengers. John Wiley and Sons, Inc, Hoboken, New Jersey.

Patala, S., Jalkala, A., Keränen, J., Väisänen, S., Tuominen, V., Soukka, R., 2016. Sustainable value propositions: framework and implications for technology suppliers. Ind. Mark. Manag. 59, 144-156. https://doi.org/10.1016 
j.indmarman.2016.03.001.

Patton, M., 1990. Qualitative Evaluation and Research Methods. Sage, Beverly Hills, CA.

Pieroni, M.P., McAloone, T., Pigosso, D.A., 2019. Business model innovation for circular economy and sustainability: a review of approaches. J. Clean. Prod. 215, $198-216$.

Powell, E., Hamann, R., Bitzer, V., Baker, T., 2018. Bringing the elephant into the room? Enacting conflict in collective prosocial organizing. J. Bus. Ventur. 33 (5) 623-642.

Quist, J., Tukker, A., 2013. Knowledge collaboration and learning for sustainable innovation and consumption: introduction to the ERSCP portion of this special volume. J. Clean. Prod. 48, 167-175. https://doi.org/10.1016 j.jclepro.2013.03.051.

Richardson, J., 2008. The Business Model: an integrative framework for strategy execution. Strateg. Chang. 17 (5-6), 133-144. https://doi.org/10.1002/jsc.821.

Rohrbeck, R., Konnertz, L., Knab, S., 2013. Collaborative business modelling for systemic and sustainability innovations. Int. J. Technol. Manag. 63 (1/2), 4-23. https://ssrn.com/abstract=2197724.

Rondinelli, D., London, T., 2003. How corporations and environmental groups cooperate: assessing cross-sector alliances and collaborations. Acad. Manag. Exec. 17, 61-76. https://doi.org/10.5465/AME.2003.9474812.

Roome, N., Louche, C., 2016. Journeying toward business models for sustainability: a conceptual model found inside the black box of organisational transformation. Organ. Environ. 29 (1), 11-35.

Santos, F.M., Eisenhardt, K.M., 2005. Organizational boundaries and theories of organization. Organ. Sci. 16 (5), 491-508. Retrieved from. http://www.jstor.org stable/25145988.

Schaltegger, S., Burritt, R., Zvezdov, D., Hörisch, J., Tingey-Holyoak, J., 2015. Management roles and sustainability information. Exploring corporate practice. Aust. Account. Rev. 25 (4), 328-345. https://doi.org/10.1111/auar.12102.

Schaltegger, S., Hansen, E.G., Lüdeke-Freund, F., 2016. Business models for sustainability: origins, present research and future avenues. Organ. Environ. 29 (1) 3-10. https://doi.org/10.1177/1086026615599806.

Schaltegger, S, Lüdeke-Freund, F., Hansen, E, 2012. Business Cases for Sustainability: The Role of Business Model Innovation for Corporate Sustainability. Int. J. Innovat. Sustain. Dev. 6 (2), 95-119. https://doi.org/10.1504/ IJISD.2012.046944.
Schreyögg, G., Sydow, J., 2010. CROSSROADS-Organizing for Fluidity? Dilemmas of New Organizational Forms. Org. Sc. 21 (6), 1251-1262. https://doi.org/10.1287/ orsc. 1100.0561.

Scott, W., 1998. Organizations: Rational, Natural and Open Systems. Canadian J. Soc. 29 https://doi.org/10.2307/2393090.

Smink, M., Negro, S.O., Niesten, E., Hekkert, M.P., 2015. How mismatching institutional logics hinder niche-regime interaction and how boundary spanners intervene. Technol. Forecast. Soc. Chang. 100 (C), 225-237.

Solaimani, S., Bouwman, H., 2012. A framework for the alignment of business model and business processes: a generic model for trans-sector innovation. Bus. Process Manag. J. 18 (4), 655-679. https://doi.org/10.1108/14637151211253783.

Stark, D., 2009. The Sense of Dissonance: Accounts of Worth in Economic Life. Princeton University Press, NJ.

Stubbs, W., Cocklin, C., 2008. Conceptualizing a "Sustainability Business Model". Org. \& Env. 21 (2), 103-127. https://doi.org/10.1177/1086026608318042.

Teece, D.J., 2010. Business models, business strategy and innovation. Long. Range Plan. 43 (2-3), 172-194.

Upward, A., Jones, P., 2016. An ontology for strongly sustainable business models: defining an enterprise framework compatible with natural and social science. Organ. Environ. 29 (1), 97-123.

Vergragt, P.J., Quist, J., 2011. Backcasting for sustainability: Introduction to the special issue. Technol. Forecast Soc. 78 (5), 747-755. https://doi.org/10.1016/ j.techfore.2011.03.010.

Vurro, C., Dacin, M.T., Perrini, F., 2010. Institutional antecedents of partnering for social change: how institutional logics shape cross-sector. Social Partnerships 94 (1), 39. https://doi.org/10.1007/s10551-011-0778-0. J. Bus. Ethics.

Witjes, S., Lozano, R., 2016. Towards a more Circular Economy: proposing a framework linking sustainable public procurement and sustainable business models. Resour. Conserv. Recycl. 112, 37-44. https://doi.org/10.1016/ j.resconrec.2016.04.015.

Yin, R.K., 1994. Case Study Research: Design and Methods. Sage Publications, London, UK.

Zietsma, C., Lawrence, T.B., 2010. Institutional work in the transformation of an organizational field: the interplay of boundary work and practice work, admin. Science Q 55, 189-221.

Zott, C., Amit, R., 2010. Business model design: an activity system perspective. Long. Range Plan. 43 (2-3), 216-226. 